\title{
21. CENOZOIC RADIOLARIANS FROM THE BARBADOS RIDGE, LESSER ANTILLES SUBDUCTION COMPLEX, DEEP SEA DRILLING PROJECT LEG 78A ${ }^{1}$
}

\author{
G. W. Renz ${ }^{2}$
}

\begin{abstract}
Radiolarians occur at two Leg 78A sites. The Barbados Ridge Site 541, $3 \mathrm{~km}$ arcward of the deformation front, includes a short radiolarian sequence at the bottom of the hole, with assemblages ranging from the lower Miocene Stichocorys delmontensis Zone through the Calocycletta costata Zone. The oceanic reference Site 543, $3 \mathrm{~km}$ seaward of the deformation front, includes a longer sequence from the middle Eocene Theocotyle cryptocephala Zone to the middle Miocene Dorcadospyris alata Zone. These sites are compared to other Deep Sea Drilling Project sites in the Caribbean and Gulf of Mexico and also to a land-based section at Bath Cliff, Barbados. Because this is the first time we have been able to document the nature of a subduction zone complex by drilling, a major objective of this chapter is a comparison of the radiolarian sequence in the deformation zone with the corresponding sequence at the oceanic reference site. The part of the section with radiolarians does not show any stratigraphic inversion, such as is documented by calcareous nannofossils higher in the hole. By comparing varying evolutionary morphologies of three unrelated taxa, a correlation is made within the Calocycletta costata Zone. This correlation, and others made in the most general manner, suggest variations in the environment or in the rate of deposition, uneven core recovery, or perhaps the tilting of beds with the down-going crust.
\end{abstract}

\section{INTRODUCTION}

Radiolarians were recovered at two sites of DSDP Leg 78A on the Barbados Ridge Complex. Site 541 is $3 \mathrm{~km}$ arcward of the deformation front and includes sediments scraped off the down-going plate. Oceanic reference Site 543 is $3 \mathrm{~km}$ west of this front (Fig. 1). The localities and water depths of these sites are:

\begin{tabular}{|c|c|c|c|c|}
\hline Hole & $\begin{array}{c}\text { Water } \\
\text { depth } \\
\text { (m) }\end{array}$ & Position & $\begin{array}{l}\text { Recovery } \\
\text { (m) }\end{array}$ & $\begin{array}{l}\text { No. of } \\
\text { cores }\end{array}$ \\
\hline 541 & 4961 & $15^{\circ} 31.2^{\prime} \mathrm{N}, 58^{\circ} 43.7^{\prime} \mathrm{W}$ & 459.0 & 50 \\
\hline 543 & 5643 & $15^{\circ} 42.7^{\prime} \mathrm{N}, 58^{\circ} 39.2^{\prime} \mathrm{W}$ & 228.4 & 34 \\
\hline $543 \mathrm{~A}$ & 5643 & $15^{\circ} 42.7^{\prime} \mathrm{N}, 58^{\circ} 39.2^{\prime} \mathrm{W}$ & 69.4 & 16 \\
\hline
\end{tabular}

A Recent assemblage occurs in the top core at Site 541. Early Miocene radiolarian assemblages occur in the three lowest cores. Drilling was terminated when the hole collapsed at $460 \mathrm{~m}$ sub-bottom depth. At Site 543, a sparse Recent assemblage occurs at the top. Midhole, a long radiolarian sequence was recovered, with assemblages ranging from middle Eocene to middle Miocene. Below this sequence are occasional sparse, partially dissolved assemblages.

Figure 2 is a summary of the radiolarian zones represented in Leg 78A. Figure 3 is a correlation of the two sites. Tables 1,2 , and 3 summarize the occurrences and abundances of species found in Holes 541, 543, and 543A, respectively.

\section{PROCEDURES}

Samples were taken at least every section, and as closely spaced as three per section, in order to describe and compare the sites adequate-

\footnotetext{
${ }^{1}$ Biju-Duval, B., Moore, J. C., et al. Init. Repts. DSDP, 78A: Washington (U.S. Govt. Printing Office).

2 Address: 3720 St. Francis Drive, Lafayette, California 94549.
}

ly. Sediments were washed and sieved at $44 \mu \mathrm{m}$. Four types of strewn slides in three size fractions ( $>149 \mu \mathrm{m}, 63-149 \mu \mathrm{m}, 44-63 \mu \mathrm{m}$, and $>44 \mu \mathrm{m}$ ) were permanently mounted.

Relative abundances of species are recorded in five categories (defined in Table 1). These categories indicate the percentage that a taxon represents of the total assemblage on the $>44-\mu \mathrm{m}$ slide. The density of radiolarians on a slide was calculated by counting eight random grids on the slide and extrapolating the average number to the whole slide. The abundance of a taxon was calculated from its numbers in 20 random grids and extrapolated to the whole slide. Near the evolutionary transition of a species, both the ancestral and the descendant taxon were counted on the whole slide to ascertain which predominates.

The radiolarian zones used in this paper are the chronozones defined by Riedel and Sanfilippo (1978), with the Thyrsocyrtis bromia Zone emended by Maurrasse and Glass (1976) and Saunders et al. (in press).

\section{SITE 541}

Hole 541 in the deformation zone was drilled with the hope of penetrating the down-going oceanic crust, an objective not previously achieved at any convergent margin. The hole collapsed at $460 \mathrm{~m}$ sub-bottom depth, and drilling was terminated.

In Core 1 (Sections 541-1-1 and 541-1,CC), sponge spicules are few and broken. Recent radiolarians are very rare, with thin-walled skeletons.

Cores 2 through 46 consist of calcareous units overlying a hemipelagic mud. Siliceous microfossils are absent.

In Section $541-47, C C$, very few and very badly preserved, unidentifiable radiolarians occur. In Cores 48 through 50, radiolarians are very rare to abundant, moderately well to poorly preserved (Table 1 ). Orosphaerid fragments are common. These early Miocene assemblages range from the Calocycletta costata Zone to the Stichocorys delmontensis Zone.

Samples 541-48-5, 105-107 cm through 541-50-1, $120-122 \mathrm{~cm}$ are assigned to the Calocycletta costata Zone and contain radiolarians in two different preservational states. Radiolarians are, in general, moderately 


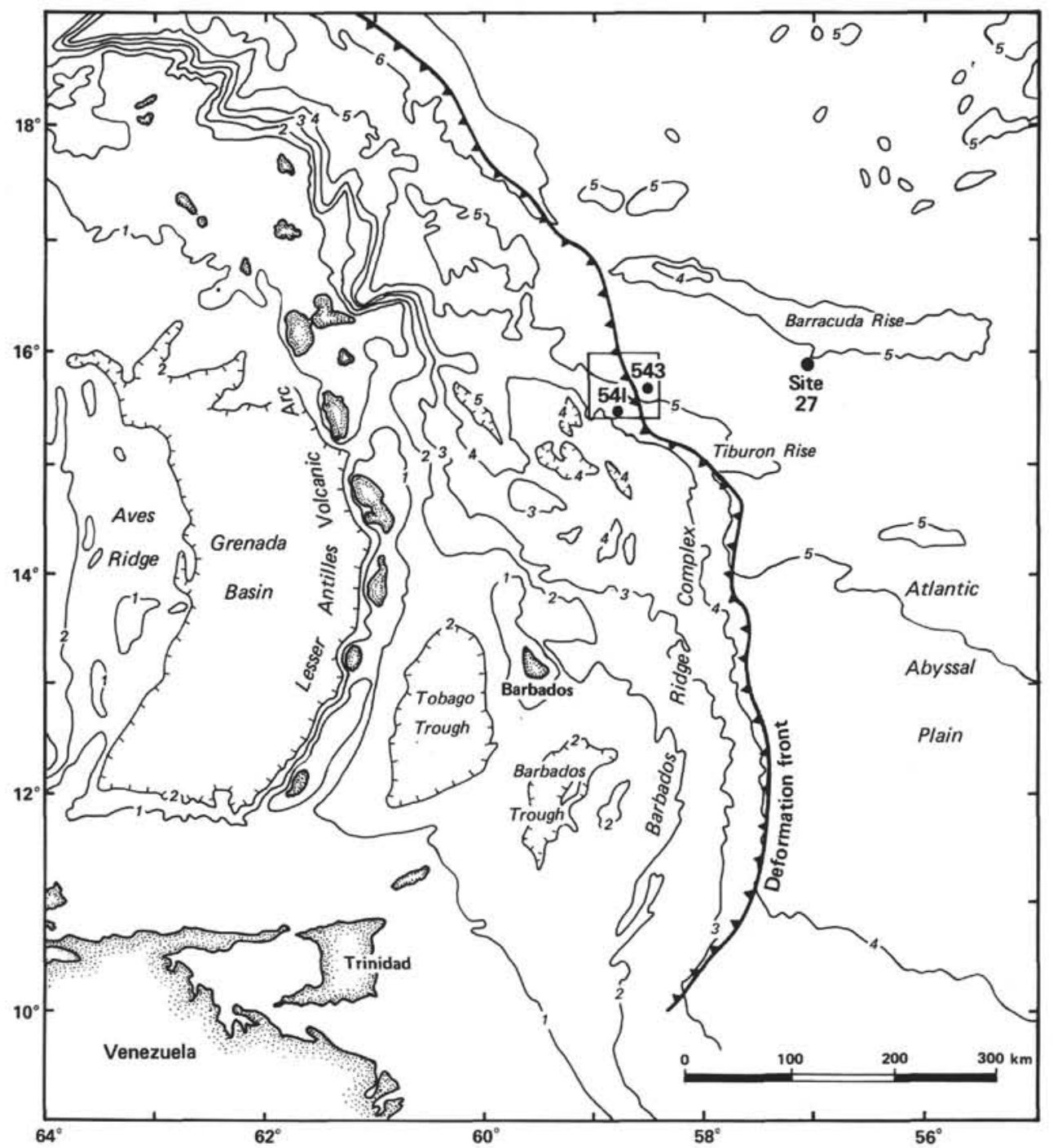

Figure 1. Leg 78A site location map.

well preserved, the exception being from Samples 541$49-1,10-12 \mathrm{~cm}$ to $541-49-3,35-37 \mathrm{~cm}$ where skeletons are quite poorly preserved. Specimens of Cyrtocapsella cornuta, Liriospyris stauropora, Calocycletta costata, C. virginis, Stichocorys delmontensis, S. wolffii, and Dorcadospyris dentata are most frequent. No specimens of Dorcadospyris alata occur, indicating that the sequence does not approach the evolutionary boundary of $D$. dentata/D. alata. Also, because of the poor recovery of Core $50(39 \%)$ and the resulting hiatus between Sections 1 and 3, the lower limit of the zone is not located.

The Stichocorys wolffii Zone is missing.

Sample 541-50-3, 12-14 cm through Section 541$50, \mathrm{CC}$ are assigned to the Stichocorys delmontensis Zone due to the appearance of Lychnocanoma elongata and Dorcadospyris ateuchus and to the disappearance of Calocycletta costata and S. wolffii. Theocyrtis anno$s a$ is absent. The assemblage is dominated by Didymocyrtis tubaria, Dorcadospyris ateuchus, Cyrtocapsella cornuta, C. tetrapera, L. elongata, Cyclampterium leptetrum, and $S$. delmontensis. Specimens of $S$. delmontensis appear almost identical with specimens of $S$. wolffii encountered slightly higher in the hole, differing only in a slightly more porous thorax (more than 6 pores/visible half).

\section{SITE 543}

Two holes (543 and 543A) were drilled at this site, in $5643 \mathrm{~m}$ of water. This oceanic reference site is $3 \mathrm{~km}$ seaward of the deformation front. Basement was reached in Hole 543A. Radiolarians in varying abundances and states of preservation were recovered from both holes. The most significant recovery is a Cenozoic sequence that ranges from middle Eocene to middle Miocene in Hole 543.

\section{Hole 543}

A sparse, Recent assemblage of radiolarians showing strong dissolution occurs in Section 543-1,CC. Cores 2 through 16 are barren. Radiolarians occur again in Section 543-17-1 and continue through the last core $(34, C C)$.

At the top of this long sequence (Sample 543-17-1, $10-12 \mathrm{~cm}$ ) are a few fragments, one of which is identi- 


\begin{tabular}{|c|c|c|c|}
\hline Epochs & Radiolarian zones & $\begin{array}{c}541 \\
\text { (core-section) }\end{array}$ & $\begin{array}{c}543 \\
\text { (core-section) }\end{array}$ \\
\hline$\underset{\dot{E}}{\stackrel{\dot{g}}{\dot{E}}}$ & D. alata & & $\begin{array}{l}17-2 \\
18-1\end{array}$ \\
\hline \multirow{4}{*}{ 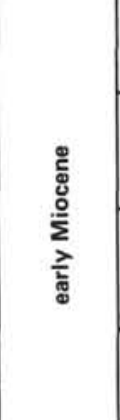 } & C. costata & $\begin{array}{l}48-5 \\
50.1\end{array}$ & $\begin{array}{l}18-2 \\
20-1\end{array}$ \\
\hline & S. wolffii & & $\begin{array}{l}20-2 \\
20, \mathrm{CC}\end{array}$ \\
\hline & S. delmontensis & $\begin{array}{l}50-3 \\
50, \mathrm{cc}\end{array}$ & 22.1 \\
\hline & L. elongata & & $\begin{array}{l}23-1 \\
24-1\end{array}$ \\
\hline \multirow{2}{*}{ 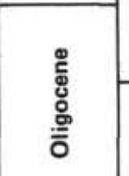 } & D. ateuchus & & $\begin{array}{l}24-2 \\
26-1\end{array}$ \\
\hline & T. tuberosa & & $\begin{array}{l}26-2 \\
27-2\end{array}$ \\
\hline WIII & C. ornata & & $\begin{array}{l}27-3 \\
27-4\end{array}$ \\
\hline 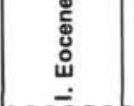 & C. bandyca & & $\begin{array}{l}27-5 \\
28-3\end{array}$ \\
\hline \multirow{6}{*}{ 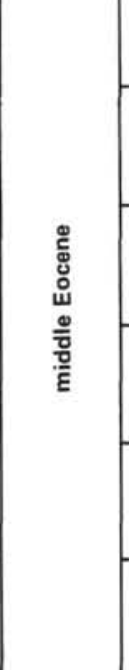 } & P. chalara & & $\begin{array}{l}28-4 \\
29-2\end{array}$ \\
\hline & P. mitra & & $\begin{array}{l}29-3 \\
30-1 \\
\text { AH1-4 }\end{array}$ \\
\hline & P. ampla & & $\begin{array}{l}30-1 \\
30-3 \\
\text { AH } 1-5\end{array}$ \\
\hline & $T$. triacantha & & $\begin{array}{l}30-3 \\
30-5\end{array}$ \\
\hline & D. mongolfieri & & $\begin{array}{l}30-6 \\
31, \mathrm{CC} \\
\mathrm{AH} 1, \mathrm{CC}\end{array}$ \\
\hline & T. cryptocephala & & $\begin{array}{l}32-1 \\
32-5 \\
\text { A2-1 }\end{array}$ \\
\hline
\end{tabular}

Figure 2. Radiolarian zones represented at Leg 78A sites. Wavy line indicates hiatus.

fied as Calocycletta costata, dating the sample as no younger than the middle Miocene Dorcadospyris alata Zone. The assemblages in Samples 543-17-2, 10-12 cm through 543-18-1, 30-32 cm show increasing abundances and better states of preservation, and are assigned to the Dorcadospyris alata Zone. The following species dominate: Dorcadospyris alata, Cyrtocapsella cornuta, Liriospyris parkerae, Calocycletta costata, Cy-

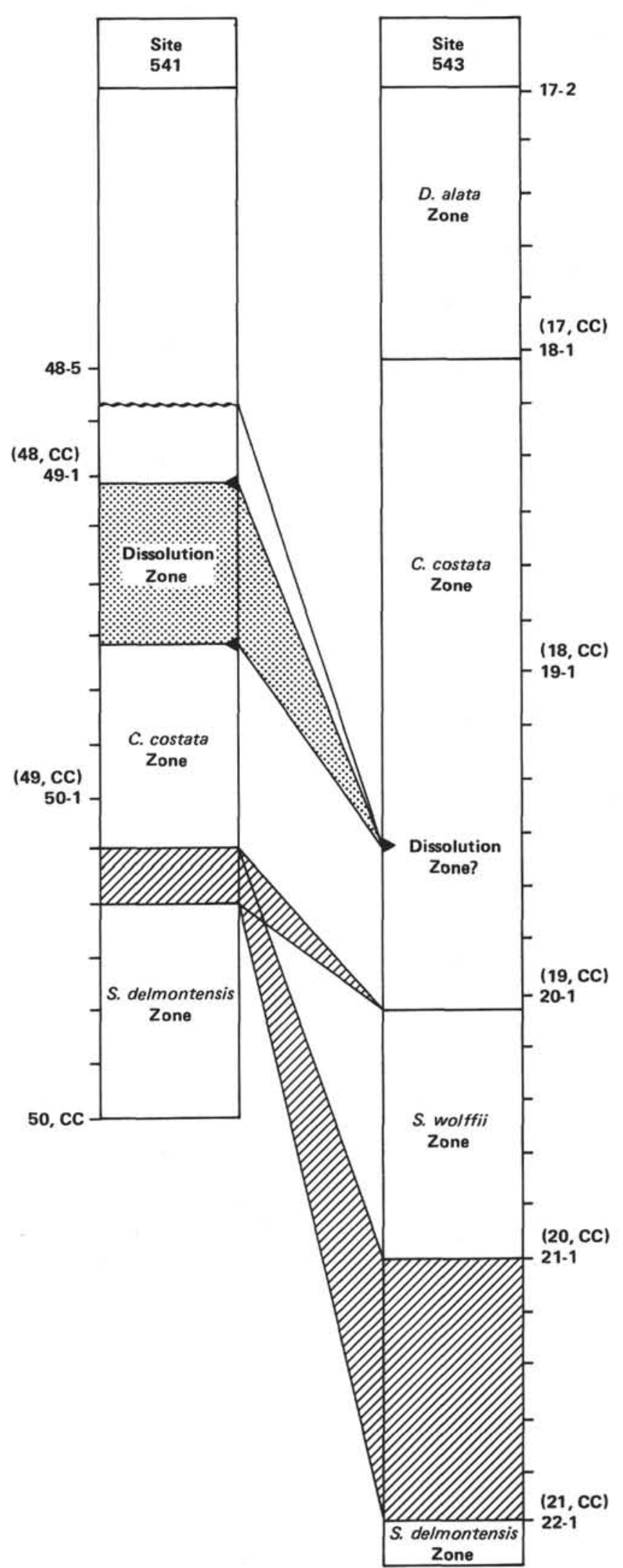

Figure 3. Radiolarian zone correlations. Hatched areas show hiatus. 
Table 1. Radiolarians at Site 541.

\begin{tabular}{|c|c|c|c|c|c|c|c|c|c|c|c|c|c|c|c|}
\hline Epoch & $\begin{array}{l}\text { Radiolarian } \\
\text { Zones }\end{array}$ & $\begin{array}{c}\text { Sample } \\
\text { (interval in } \mathrm{cm} \text { ) }\end{array}$ & 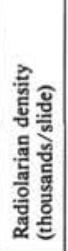 & 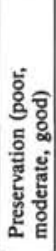 & 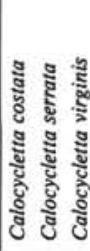 & & & 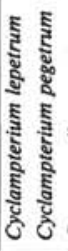 & & & & 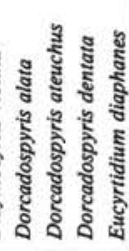 & 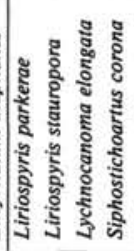 & & 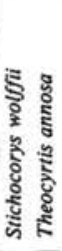 \\
\hline \multirow[t]{3}{*}{ early Miocene } & C. costata & $\begin{array}{l}48-5,105-107 \\
48-6,87-89 \\
48, C C \\
49-1,10-12 \\
49-2,20-22 \\
49-2,108-110 \\
49-3,35-37 \\
49-1,40-42 \\
49-4,105-107 \\
49-5,90-92 \\
49, C C \\
50-1,20-22 \\
50-1,120-122\end{array}$ & \begin{tabular}{r|}
20.6 \\
8.2 \\
14.0 \\
$<.1$ \\
$<.1$ \\
$>0$ \\
1.3 \\
15.8 \\
13.4 \\
16.9 \\
19.2 \\
17.4 \\
19.9 \\
\end{tabular} & $\begin{array}{l}\mathrm{M} \\
\mathrm{M} \\
\mathrm{M} \\
\mathrm{P} \\
\mathrm{P} \\
\mathrm{P} \\
\mathrm{P} \\
\mathrm{M} \\
\mathrm{M} \\
\mathrm{M} \\
\mathrm{M} \\
\mathrm{M} \\
\mathrm{M}\end{array}$ & 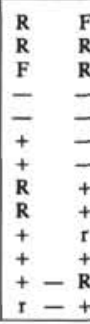 & $\begin{array}{ll}\mathrm{F} & \mathrm{r} \\
\mathrm{R} & + \\
\mathrm{R} & \mathrm{R} \\
& \mathrm{R} \\
& - \\
& = \\
& = \\
+ & \mathrm{R} \\
+ & + \\
\mathrm{r} & + \\
+ & + \\
\mathrm{R} & + \\
+ & +\end{array}$ & $\begin{array}{l}\mathbf{R} \\
\mathrm{R} \\
\mathrm{F} \\
\mathbf{Z} \\
\mathbf{Z} \\
\mathbf{F} \\
\mathrm{F} \\
\mathrm{R} \\
\mathrm{R} \\
\mathrm{F} \\
\mathrm{R}\end{array}$ & $\begin{array}{l}+ \\
+ \\
+ \\
+ \\
+ \\
\pm \\
+ \\
+ \\
\text { R } \\
+ \\
\text { R } \\
+ \\
+ \\
+\end{array}$ & $\begin{array}{l}\mathrm{F} \\
\mathrm{R} \\
\mathrm{F} \\
\\
\\
+ \\
\\
\mathrm{F} \\
\mathrm{F} \\
\mathrm{F} \\
\mathrm{R} \\
\mathrm{F} \\
\mathrm{F} \\
\end{array}$ & $\stackrel{+}{ \pm}+$ & \begin{tabular}{|l} 
\\
$\mathrm{r}$ \\
+ \\
\\
- \\
\\
$\mathrm{r}$ \\
$\mathrm{r}$ \\
$\mathrm{R}$ \\
$\mathrm{r}$ \\
$\mathrm{r}$ \\
+ \\
\end{tabular} & 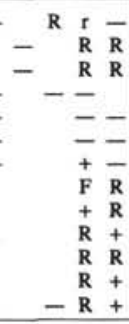 & 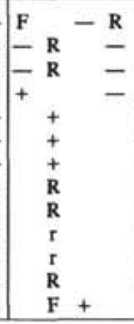 & \begin{tabular}{l|l}
$\mathbf{F}$ & $\mathbf{F}$ \\
$\mathbf{R}$ & \\
- & \\
- & \\
& \\
$\mathbf{R}$ & \\
$\mathbf{F}$ & \\
$\mathbf{R}$ & \\
+ & \\
+ & \\
$\mathbf{F}$ &
\end{tabular} & $\begin{array}{l}\mathrm{F} \\
\mathrm{F} \\
- \\
\\
+ \\
\mathrm{F} \\
\mathrm{C} \\
\mathrm{F} \\
\mathrm{F} \\
\mathrm{C} \\
\mathrm{F}\end{array}$ \\
\hline & Hiatus & & & & & & & & & & & & & & \\
\hline & S. delmontensis & $\begin{array}{l}50-3,12-14 \\
50-3,30-32 \\
50-3,133-135 \\
50-4,43-45 \\
50, \mathrm{CC}\end{array}$ & \begin{tabular}{l|}
19.7 \\
20.5 \\
16.7 \\
12.9 \\
22.6
\end{tabular} & $\begin{array}{l}\mathrm{M} \\
\mathrm{M} \\
\mathrm{m} \\
\mathrm{M} \\
\mathrm{M}\end{array}$ & $\begin{array}{r}-r \\
-r \\
-r \\
-r \\
r \\
r\end{array}$ & $\begin{array}{r}-R \\
-\quad r \\
R \\
R \\
r\end{array}$ & & $\begin{array}{ll}R & + \\
r & r \\
R & + \\
R & + \\
r & r\end{array}$ & $\begin{array}{l}\mathbf{R} \\
\mathbf{R} \\
\mathbf{F} \\
\mathbf{F} \\
\mathbf{F}\end{array}$ & $\begin{array}{ll}\mathbf{R} & \mathrm{T} \\
\mathrm{R} & \mathrm{R} \\
\mathrm{R} & \mathrm{r} \\
+ & + \\
\mathbf{R} & \mathbf{r} \\
& \end{array}$ & 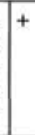 & $\begin{array}{rr}\mathbf{R} & -+ \\
\mathrm{R} & -\mathrm{R} \\
\mathrm{R} & \mathrm{R} \\
\mathrm{R} & + \\
\mathrm{R} & \mathrm{T}\end{array}$ & $\begin{array}{r}-+ \\
=\quad R \\
-\quad R \\
\quad+ \\
r\end{array}$ & \begin{tabular}{l|l}
$R$ & \\
$R$ & \\
$r$ & \\
+ & \\
$R$ &
\end{tabular} & $\bar{z}$ \\
\hline
\end{tabular}

Note: Present but less than $0.01 \%=+; 0.01 \%-0.1 \%=\mathrm{r}$ (very rare); $0.1 \%-1 \%=\mathrm{R}$ (rare); $1-10 \%=\mathrm{F}$ (few); $>10 \%=\mathrm{C}$ (common); looked for, but absent $=-$; blank space indicates species not looked for.

clampterium leptetrum, Stichocorys delmontensis, and S. wolffii.

In Samples 543-18-2, 31-33 cm through 543-20-1, $70-72 \mathrm{~cm}$, Dorcadospyris dentata is consistently more abundant than its descendant, $D$. alata. This fact, along with the continuing occurrence of Calocycletta costata and $C$. virginis, the morphotypic top of Siphostichoartus corona and Didymocyrtis violina, and the evolutionary top of Liriospyris stauropora, places these samples in the lower Miocene Calocycletta costata Zone. The upper radiolarian sequence at Site 541 (Section 541-48-5) correlates with the bottom third of this zone (Fig. 3).

Sample 543-20-2, 70-72 cm through Section 543$20, \mathrm{CC}$ are assigned to the Stichocorys wolffii Zone. S. wolffii, $S$. delmontensis, Eucyrtidium diaphanes, $C y$ clampterium leptetrum, Carpocanopsis cingulata, C. bramlettei, and Cyrtocapsella cornuta dominate; the evolutionary top of Didymocyrtis tubaria occurs; Calocycletta costata is absent. Radiolarians are very abundant, occurring in highly diverse assemblages of moderate preservation.

There was no recovery from Core 21 . What little was recovered from Core 22 (Section 543-22-1, top-approximately $25 \mathrm{~cm}^{3}$ ) is assigned to the Stichocorys delmontensis Zone (see Table 2). S. delmontensis, Didymocyrtis prismatica, Cyrtocapsella cornuta, C. tetrapera, Calocycletta serrata, Dorcadospyris ateuchus, and Eucyrtidium diaphanes dominate the assemblage. $S$. wolffii and Theocyrtis annosa are notably absent. Specimens are very abundant and very well preserved.

Samples 543-23-1, 145-147 cm through 543-24-1, 2$4 \mathrm{~cm}$ (again, see Table 2) have common to abundant radiolarians, and the quality of preservation remains moderately good. This sequence is placed in the Lychnocanoma elongata Zone. L. elongata, D. ateuchus and
T. annosa (both morphotypic tops), Cyclampterium pegetrum (evolutionary top), and Didymocyrtis prismatica dominate the assemblage. Calocycletta serrata and Cyrtocapsella tetrapera are absent. C. cornuta occurs in only the first two samples. This assignment indicates that the Cyrtocapsella tetrapera Zone may have occurred in the lost Core 22.

Samples 543-24-2, 40-42 cm through 543-26-1, 64-66 $\mathrm{cm}$ show a rapid decline in the quality of preservation and a great variability in abundance. The assemblages have very low diversities, being dominated by Dorcadospyris ateuchus and occasionally by Cyclampterium pegetrum. L. elongata is absent and the evolutionary top of Tristylospyris triceros has not been reached, placing these samples in the Dorcadospyris ateuchus Zone. The Oligocene/Miocene boundary occurs within this interval.

The Theocyrtis tuberosa Zone is represented by Samples 543-26-2, 43-45 cm through 543-27-2, 126-128 cm. The following species appear: Artophormis gracilis, Lithocyclia angusta, T. tuberosa, C. pegetrum, C. milowi, and Tristylospyris triceros. Abundances and the quality of preservation improve. T. triceros is dominant, and the Lithocyclia aristotelis group has not yet appeared.

Two samples, 543-27-3, 53-55 cm and 543-27-4, 78$80 \mathrm{~cm}$, are assigned to the Cryptoprora ornata Zone (Saunders et al., in press). Thyrsocyrtis tetracantha goes to extinction just below these samples; specimens of the $L$. artistotelis group occur with great frequency; and $L$. angusta drops out-all in accordance with the definition of this interval-chronozone. The assemblage includes Tristylospyris triceros, Theocyrtis tuberosa, Lychnocanoma bajunensis, and the latest occurrences of Lophocyrtis jacchia and Lychnocanoma amphitrite. The Eocene/Oligocene boundary is not yet firmly established 
Table 2A. Radiolarians in Hole 543: early Miocene to middle Miocene.

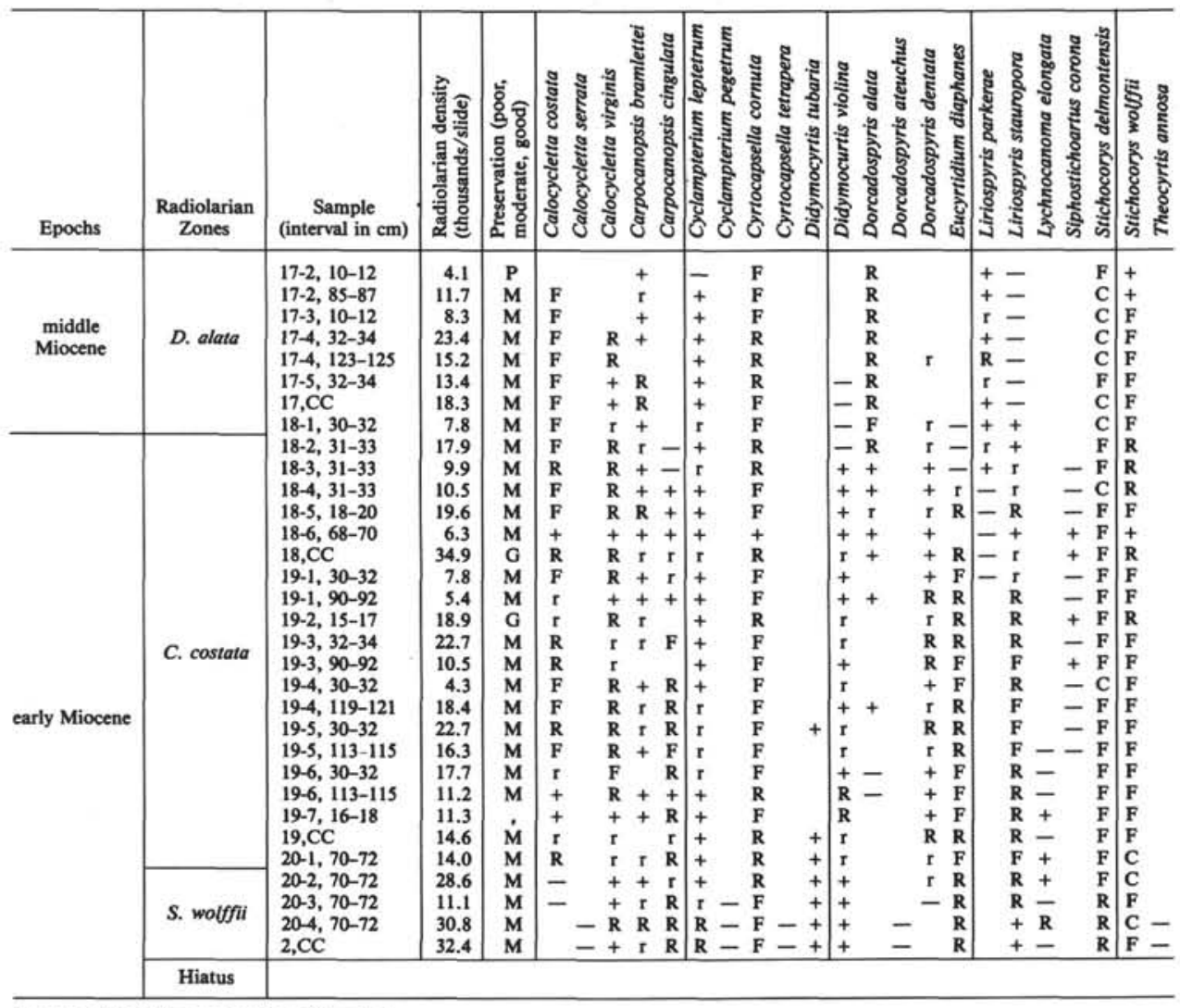

Note: See Table 1 for explanation of symbols.

Table 2B. Radiolarians in Hole 543: Oligocene to early Miocene.

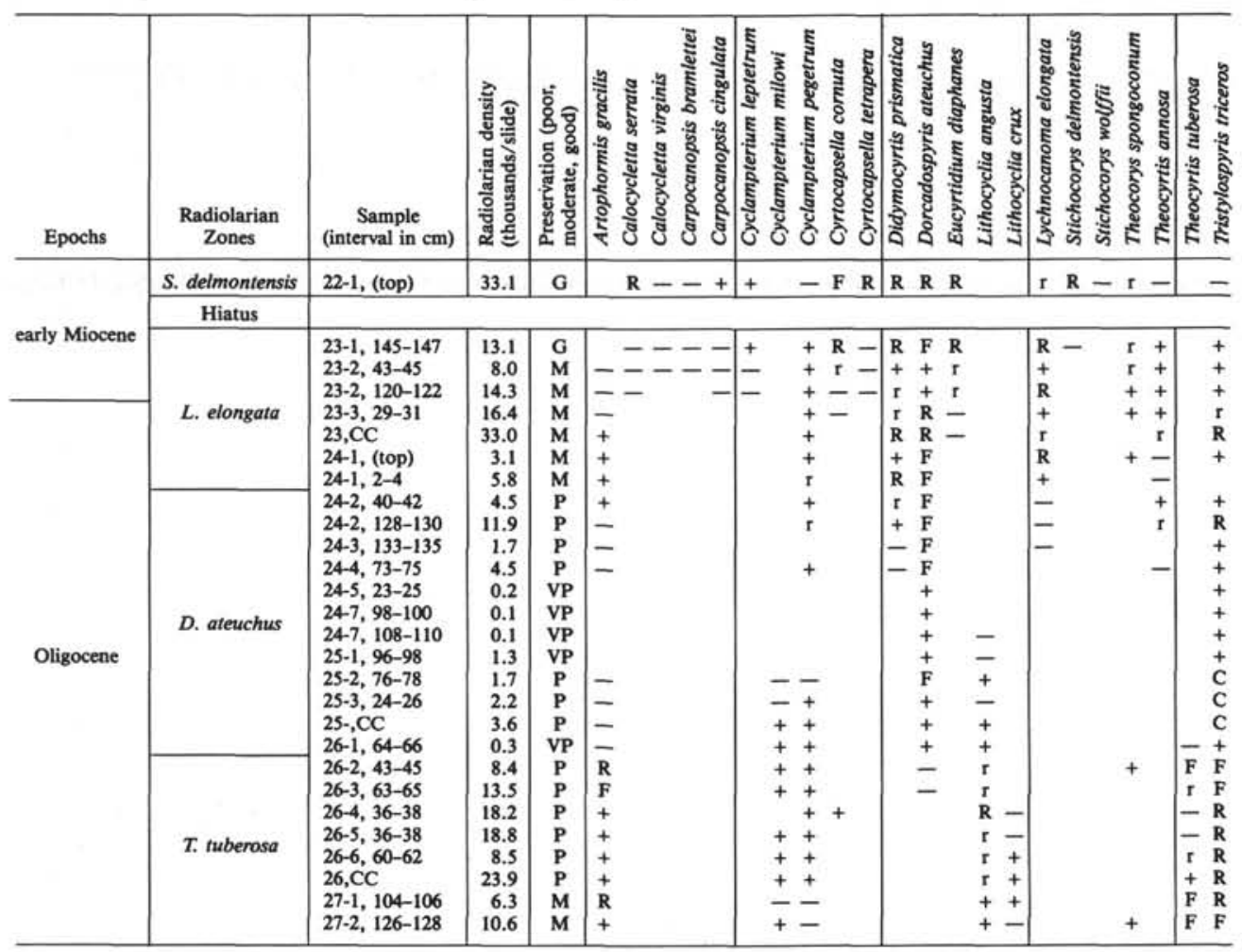

Note: See Table 1 for an explanation of symbols; data on Section 22-1 (top) and 24-1 (top) were only examined by this author because of the very small amount of the Samples (approximately $25 \mathrm{~cm}^{3}$ ). 
Table 2C. Radiolarians in Hole 543: middle Eocene to late Eocene.

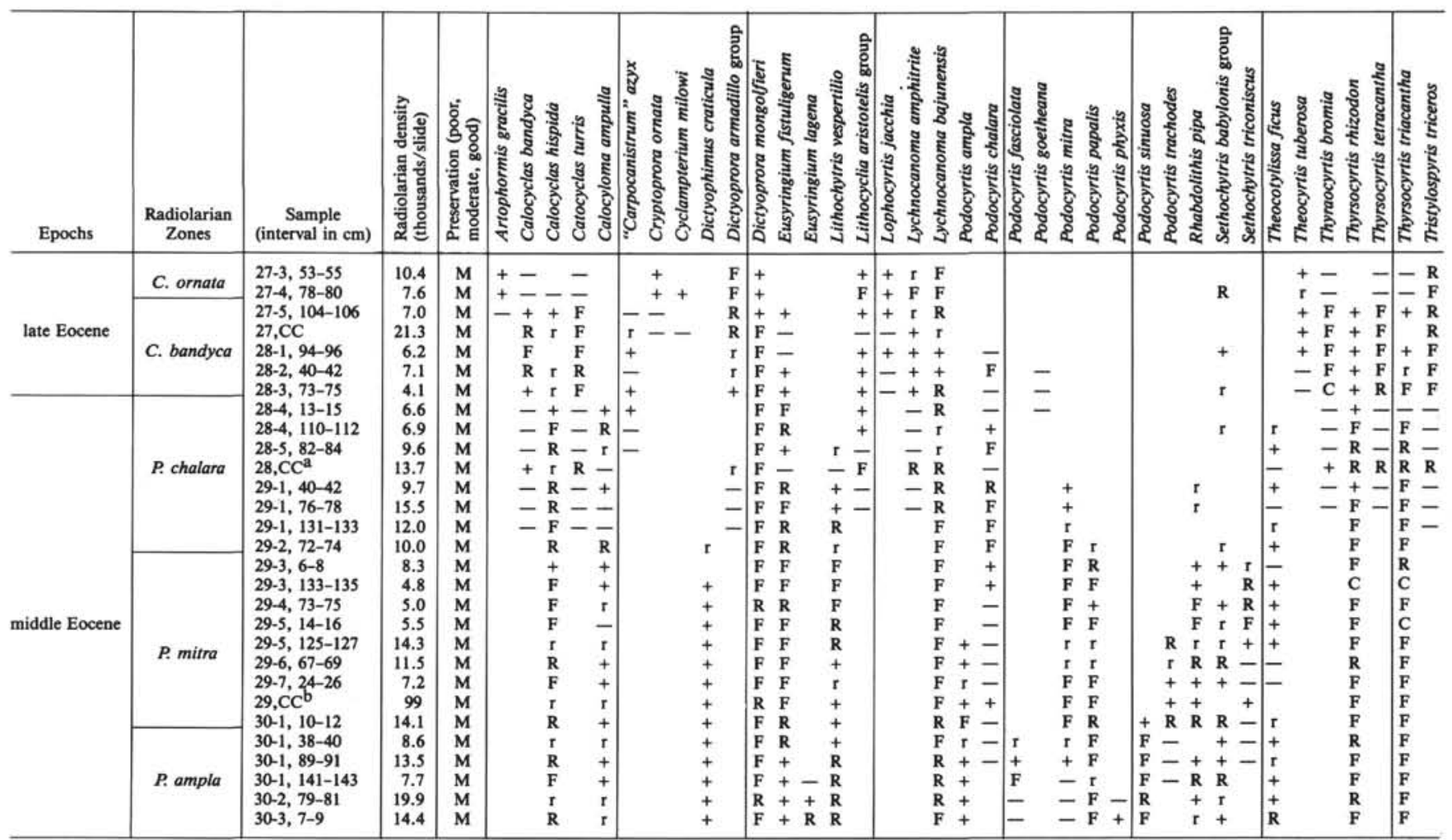

Note: See Table 1 for an explanation of symbols.

a Reworked sediment from $C$. bandyca Zone.

Reworked sediment from late $P$ mitra Zone.

in radiolarian stratigraphy and can therefore not be placed more precisely than between Samples 543-27-2, $126-128 \mathrm{~cm}$ and $543-27-5,104-106 \mathrm{~cm}$.

The assemblages in Samples 543-27-5, 104-106 cm through 543-28-3, 73-75 cm belong to the Calocyclas bandyca Zone (Saunders et al., in press) and include Tristylospyris triceros, Lithocyclia aristotelis group, Lophocyrtis jacchia, L. amphitrite, Dictyoprora mongolfieri, and the latest occurrences of Thyrsocyrtis bromia, T. tetracantha, Eusyringium fistuligerum, Calocyclas turris, and C. bandyca. "Carpocanistrum" azyx occurs very rarely and sporadically. Radiolarians are abundant and moderately well preserved.

The "Carpocanistrum" azyx Zone and the Podocyrtis goetheana Zone should follow but are not encountered in this sequence. If the absence of this section is real, it should not be the result of poor core recovery, but is more likely due to erosion. On the other hand, there may not be a real hiatus-the zones may be so thin that they were missed in sampling. The "hiatus" is indicated by the disappearance of the dominant taxa Calocyclas turris, Thyrsocyrtis bromia, T. tetracantha, and Tristylospyris triceros and by the sudden increase in frequency of Eusyringium fistuligerum. Very late specimens of Podocyrtis chalara, easily and earlier confused with $P$. goetheana, are frequently found in Sample 543$28-2,40-42 \mathrm{~cm}$, and Section 543-28,CC contains reworked radiolarians from the Calocyclas bandyca Zone.
Samples 543-28-4, 110-112 cm through 543-29-2, 72 $74 \mathrm{~cm}$ are assigned to the Podocyrtis chalara Zone. Calocyclas hispida, Dictyoprora mongolfieri, Eusyringium fistuligerum, Lychnocanoma bajunensis, $P$. chalara, and Thyrosocyrtis triacantha dominate the assemblage. Radiolarians are abundant and moderately well preserved.

Samples 543-29-3, 6-8 cm through 543-30-1, 10-12 cm are assigned to the Podocyrtis mitra Zone. $P$. chalara appears sporadically and continuously decreases in abundance until it disappears in the middle of the sequence, whereas $P$. mitra is present continuously but with fluctuating abundance. $P$. sinuos $a$ occurs only at the bottom of the sequence. Section 543-29,CC contains a displaced component from the top of the Podocyrtis mitra Zone. Radiolarians are abundant and moderately well preserved.

Samples 543-30-1, 38-40 cm through 543-30-3, 7-9 cm belong to the Podocyrtis ampla Zone. $P$. sinuosa is consistently more abundant than $P$. mitra, which disappears in the middle of the zone. $P$. ampla is present throughout; $P$. phyxis occurs very rarely at the bottom of the zone. Other dominant taxa include $C$. hispida, D. mongolfieri, $L$. bajunensis, $P$ papalis, and $T$. triacantha. Radiolarians are abundant and moderately well preserved.

Samples 543-30-3, 132-134 cm through 543-30-5, $129-131 \mathrm{~cm}$ are assigned to the Thyrsocyrtis triacantha Zone. P. phyxis and E. fistuligerum are absent, whereas 
Table 2D. Radiolarians in Hole 543: middle Eocene.

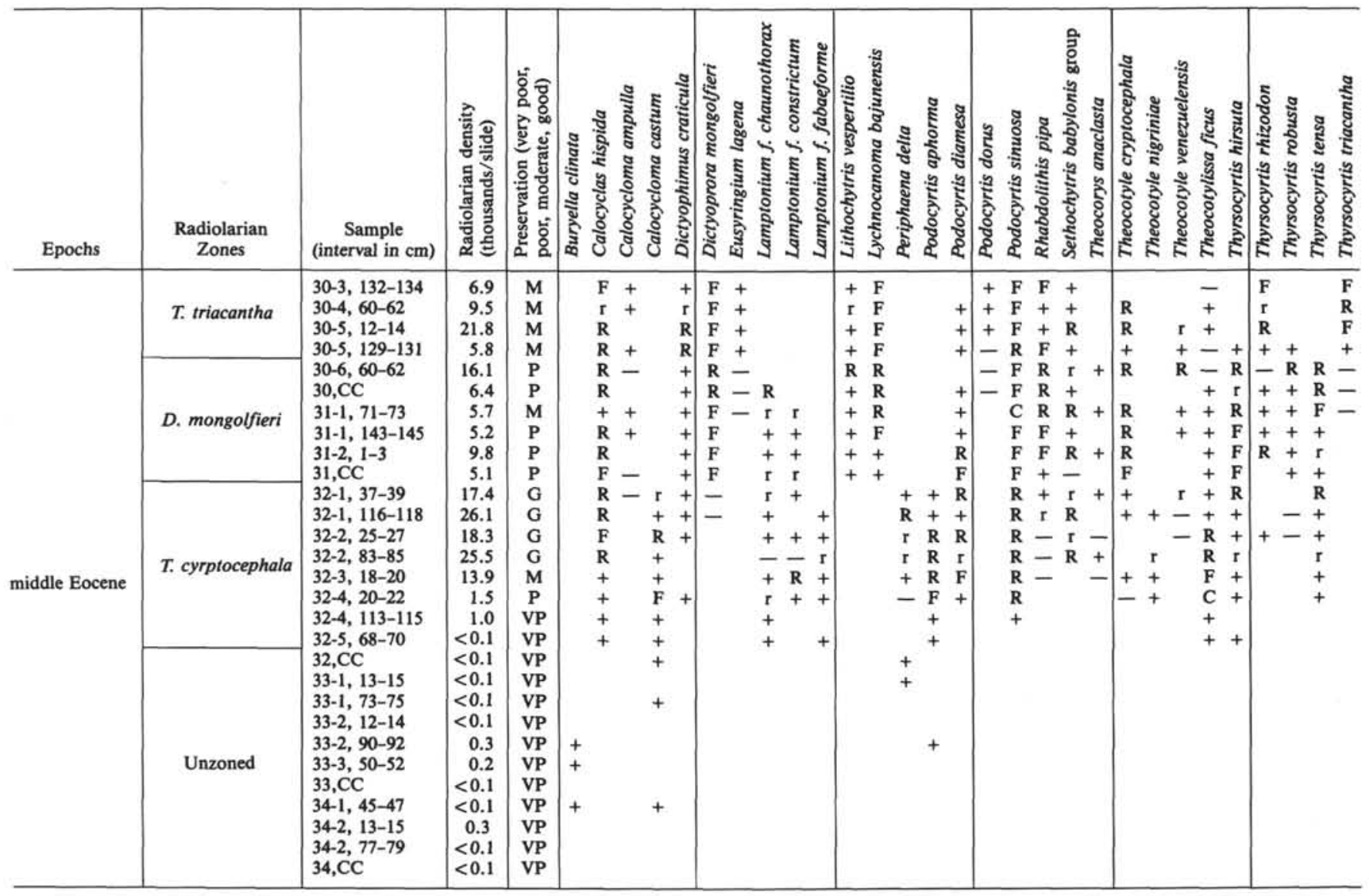

Note: See Table 1 for an explanation of symbols.

Theocotyle venezuelensis appears with increasing abundance. Specimens of $D$. mongolifieri, Thyrsocyrtis triacantha, C. hispida, Rhabdolithis pipa, P. sinuosa, and L. bajunensis predominate. Radiolarians are common and moderately well preserved.

Sample 543-30-6, 60-62 cm through Section 543$31, \mathrm{CC}$ are assigned to the Dictyoprora mongolfieri Zone due to the presence of $D$. mongolfieri in considerable numbers and to the absence of Eusyringium lagena. $P$. sinuosa, L. bajunensis, $C$. hispida, and T. hirsuta occur frequently. Radiolarians are abundant and moderately well preserved.

The top of the sequence from Samples 543-32-1, 37$39 \mathrm{~cm}$ through $543-32-5,68-70 \mathrm{~cm}$ has very abundant and very well preserved specimens. Both abundance and preservation decline to the point that skeletons at the bottom are rare and dissolved almost beyond recognition. The assemblage is dominated by Theocotylissa ficus, $C$. hispida, and $P$. sinuosa. Specimens superficially similar to $D$. mongolfieri are common, but they lack strict longitudinal pore alignment and ribs. Calocycloma castum and Periphaena delta appear with increasing abundance. This sequence is assigned to the Theocotyle cryptocephala Zone in accord with its definition, although specimens of $T$. cryptocepahala occur rarely and sporadically.
Sections 543-32,CC through 543-34,CC are unzoned because assemblages are sparse and very poorly preserved. Specimens of C. castum, Calocyclas hispida, and Theocotylissa ficus occur rarely and cannot be used with confidence for zonation. Species of the genera Amphicraspedum and Spongodiscus dominate the assemblages.

\section{Hole 543A}

During offset drilling we recovered one core from the surface, washed down to $332 \mathrm{~m}$, and continuously cored to $411 \mathrm{~m}$ at basement and $44 \mathrm{~m}$ into basalt.

Sections 543A-1-3 and 543A-1,CC contain a Recent radiolarian assemblage of low to moderate diversity, showing breakage and signs of dissolution. Sample $543 \mathrm{~A}-\mathrm{H} 1-1$ is barren.

After voids in the recovery, samples 543A-H1-4, 95$97 \mathrm{~cm}$ through $543 \mathrm{~A}-2-1,95-97 \mathrm{~cm}$ contain common to few radiolarians in moderate to poor states of preservation (Table 3). Sample 543A-Hl-4, 95-97 cm contains specimens of Podocyrtis mitra, P. trachodes, and Sethochytris triconiscus, placing it in the Podocyrtis mitra Zone. This assignment correlates best with samples from Section 543-29-7.

Rare specimens of Eusyringium fistuligerum and $P$. dorus, and the common occurrence of $P$. sinuosa, place 
Table 3. Radiolarians in Hole 543A.

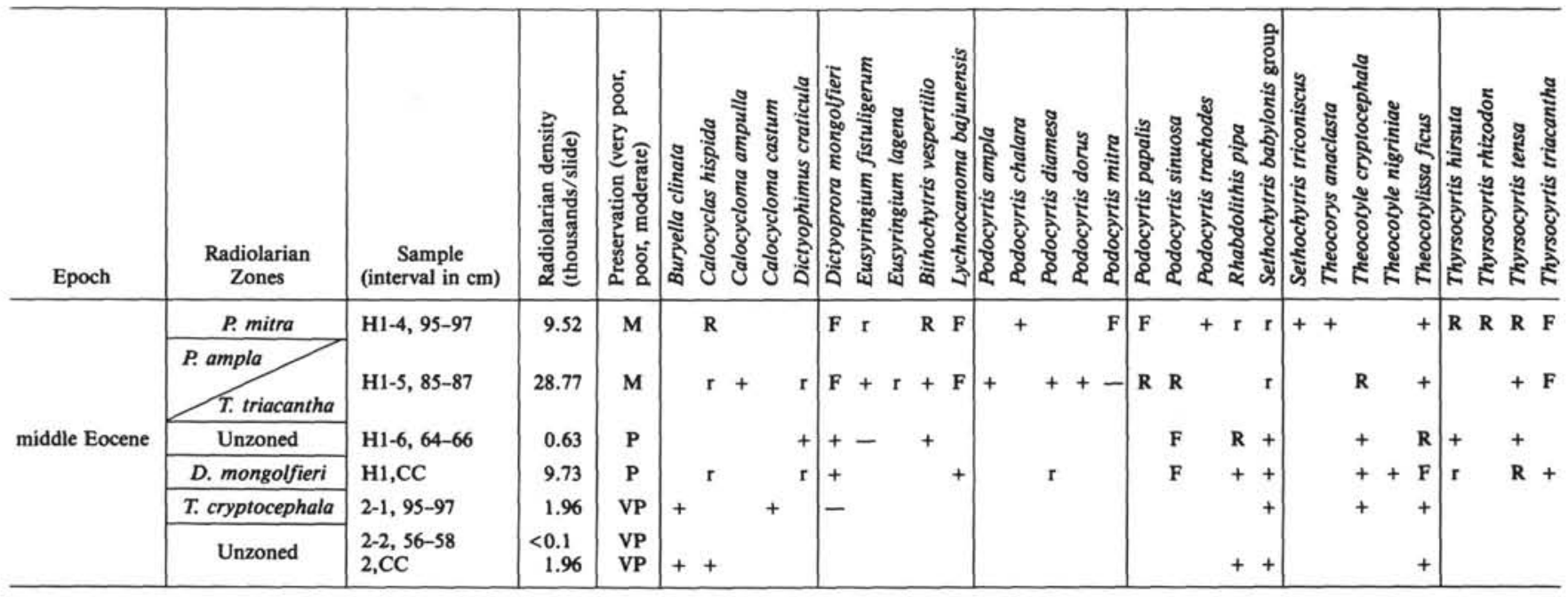

Note: See Table 1 for an explanation of symbol.

Sample 543A-H1-5, 85-87 cm at the boundary between the Podocyrtis ampla and Thyrsocyrtis triacantha Zones. This assignment correlates closest with Section 543-303 . Radiolarians are abundant and moderately well preserved.

Sample 543A-H1-6, 64-66 cm contains no diagnostic species. Specimens are few and very poorly preserved. $P$. sinuosa and Rhabdolithis pipa are dominant.

Section 543A-H1,CC contains specimens of both Theocorys anaclasta and Dictyoprora mongolfieri, placing it in the Dictyoprora mongolfieri Zone. Specimens of $T$. triacantha are rare in comparison to those of $T$. tensa. Periphaena delta is absent. This information places the sample near the middle of the zone, which correlates best with Section 543-31-1.

Sample 543A-2-1, 95-97 cm contains an abundant, highly diverse assemblage, very poorly preserved. Calocycloma castum, Theocotyle cryptocephala, and Theocotylissa ficus are present. This sample is assigned to the Theocotyle cryptocephala Zone, and correlates best with Section 543-32-4.

Sections 543A-2-2 and 543A-2,CC contain radiolarians in moderate abundance but very poorly preserved. Several specimens of $C$. castum and Buryella clinata occur.

Cores 3,4 , and 5 contain radiolarians in varying abundances, but so poorly preserved that specimens are unrecognizable. Cores 6 to basement are barren.

\section{DISCUSSION}

The pattern of radiolarian occurrences from the Barbados Ridge follows that described from land-based studies and from DSDP Legs $4,7,10,15$, and 68 , which have shown that radiolarians, and siliceous microfossils in general, do not occur in Tertiary sediments younger than middle Miocene in the Gulf of Mexico and the Caribbean (Sanfilippo and Riedel, 1973, 1976; Riedel and Sanfilippo, 1970, 1971, 1973; Riedel and Westberg, in press). At Site 541 within the deformation zone, radiolarians were found only in the top core (a Recent as- semblage showing signs of dissolution) and bottom four cores (Calocycletta costata Zone and Stichocorys delmontensis Zone of the upper lower Miocene). Even as far east as the oceanic reference Site 543, radiolarians again occur in the top core, disappear, and then reappear in a long, continuous sequence from Cores 17 through 34 at the bottom of the hole (Dorcadospyris alata Zone of the middle Miocene to Theocotyle cryptocephala Zone of the middle Eocene).

Site 543 can be compared also with the results of a land-based study by Saunders et al. (in press) on the Eocene to lower Oligocene section at Bath Cliff, Barbados. Noted differences are the rare and intermittent occurrence of "Carpocanistrum" azyx at Site 543, and the tbsence of the "Carpocanistrum" azyx and Podocyrtis goetheana Zones (see Table 2). Radiolarian events in the two sections are summarized in Table 4.

As for the intracomparison of the Miocene portions at Sites 541 and 543, there are several questions to be asked. What has happened to the radiolarians in the deformation zone? Can one measure the integrity of the section? Can the amount of compaction be quantified? Why is the Dorcadospyris alata Zone missing from Site 541 ? To answer these questions, one must first determine what part of the Calocycletta costata Zone in Site 543 is represented in Site 541.

With this objective, the evolution of morphological traits in three taxa was measured and plotted. (1) The first trait is the width and height of the thorax in $C y$ clampterium leptetrum. These proportions are known to change through the time represented by the Calocycletta costata Zone and thus offer promise for fine-scale correlation. (2) Second is the volume of the cephalis of Dorcadospyris dentata. Both the evolutionary top and the morphotypic bottom of $D$. dentata occur in Site 543. At the top of the zone there is great similarity in the cephalis between $D$. dentata and its descendant $D$. alata. Measuring the evolutionary change of the cephalis down the zone would help correlate the location of Site 541 within the zone. (3) Last is the width of the cos- 
Table 4. Radiolarian events at Site 543, DSDP Leg 78A and Bath Cliff, Barbados (Saunders et al., in press).

\begin{tabular}{|c|c|c|c|c|}
\hline & \multirow[b]{2}{*}{ Events } & \multicolumn{2}{|c|}{$\begin{array}{c}\text { Bracketing samples } \\
\text { from }\end{array}$} & \multirow[b]{2}{*}{ Radiolarian Zone } \\
\hline & & Site 543 & Bath Cliff & \\
\hline $\mathrm{Tm}$ & Lithocyclia crux & $\begin{array}{l}26-5 \\
26-6\end{array}$ & $\begin{array}{l}\text { BC93 } \\
\text { RC89 }\end{array}$ & \\
\hline \multirow{3}{*}{$\mathrm{Bm}$} & Lithocyclia crux & $27-1$ & BC82 & T. tuberosa \\
\hline & & $27-2$ & BC80 & \\
\hline & Lithocyclia aristotelis group & $27-2$ & BC80 & \\
\hline$\vec{C}$ & L. angusta & $27-3$ & BC79 & \\
\hline \multirow{2}{*}{ Tm } & Lychnocanoma amphitrite & $27-2$ & BC79 & \\
\hline & & $27-3$ & BC78 & \\
\hline \multirow{3}{*}{ Tm } & Dictyprora mongolfieri & $27-2$ & BC79 & C. ornata \\
\hline & & $27-3$ & BC78 & \\
\hline & Lophocyrtis jacchia & $27-2$ & BC78 & \\
\hline $\mathrm{Tm}$ & & $27-3$ & BC77 & \\
\hline \multirow{2}{*}{$\mathrm{Tm}$} & Thyrsocyrtis bromia & $27-4$ & BC70 & \\
\hline & & $27-5$ & ВC69 & \\
\hline \multirow{2}{*}{$\mathrm{Tm}$} & Calocyclas turris & $27-4$ & BC70 & \\
\hline & & $27-5$ & BC69 & \\
\hline \multirow{3}{*}{$\mathrm{Tm}$} & Calocyclas bandyca & $27-4$ & ВС69 & C. bandyca \\
\hline & & $27-5$ & BC68 & \\
\hline & Eusyringium fistuligerum & $27-4$ & BC54 & \\
\hline $\mathrm{Tm}$ & & $27-5$ & вC53 & \\
\hline \multirow{2}{*}{$\mathrm{Tm}$} & Thyrsocyrtis tetracantha & $27-4$ & BC69 & \\
\hline & & $27-5$ & BC68 & \\
\hline \multirow{2}{*}{$\mathrm{Tm}$} & "Carpocanistrum" azyx & $27-5$ & BC70 & \\
\hline & & $27, \mathrm{CC}$ & ВС69 & \\
\hline \multirow{2}{*}{$\mathrm{Bm}$} & Theocyrtis tuberosa & $28-1$ & BC62 & \\
\hline & & 28-2 & BC60 & \\
\hline
\end{tabular}

Note: $\mathrm{Tm}=$ morphotypic top; $\mathrm{Bm}=$ morphotypic bottom; $\rightarrow$ indicates evolutionary direction.

tae in Calocycletta costata, which show marked development after the species branches off from $C$. virginis. The results of these measurements are graphically summarized in Figures 4, 5, and 6. In each sample 5 to 12 specimens were measured, the numbers averaged, and the standard deviations recorded.

The study of the thoracic development in Cyclampterium leptetrum at Site 543 shows two sets of values for the quotient height/width. The "lower" values occur higher in the zone, whereas the "higher" values appear in the lower third. Without knowing the correlation for sample spacing at Site 541 , I simply compared the quotient values to the Site 543 graph (Fig. 4). The highest and lowest values are marked on the graph and show that all the Site 541 values "fit" in the lower third of the zone. Even the trend of values for both sites are quite similar in the bottom $5 \mathrm{~m}$.

The study of the cephalic development of Dorcadospyris dentata at Site 543 shows again two sets of values for the changing volume (height $\times$ width). The "lower" numbers occur higher in the zone as expected nearing the $D$. dentata/D. alata boundary. The "higher" values occur in the bottom half of the zone. The calculated values for Site 541 again "fit" into the lower half of the zone with the trends in values showing some similarity but not as great as that seen in Cyclampterium leptetrum.

The study of the ridge development on the thorax of Calocycletta costata shows a different trend. Early in its evolution from $C$. virginis, the thoracic ridges are less prominent, as they are at the end of the lineage. The most robust ridges occur toward the middle of its development. Thus the results here show three sets of num- bers-low at the top half of the zone, high at the third quater, and low again in the bottom quarter. The calculated values for Site 541 could "fit" either low set for Site 543 but coordinates best with the lowest quarter when compared with the two studies discussed. Here the trends in values are less easy to compare and appear to be similar only in their variability.

The results of these three studies show that the approximately $10 \mathrm{~m}$ of sediment in the Calocycletta costata Zone of Site 541 correlate to the lower portion (4-8 $\mathrm{m}$ ) of the same zone in Site 543. It would be nice to be able to compare each assemblage according to the frequencies of individual taxa, which could perhaps indicate the degree of compaction in the down-going section. But to do this the beds would have to be relatively flat or at least at comparable degrees of tilt. The greater apparent thickness of the lower third of the Calocycletta costata Zone at Site 541 may result from tilting of these beds as they are being downthrust. This may be supported by comparing a zone of radiolarian dissolution (between Samples 541-49-1, 10-12 cm and 541-49-3, 35$37 \mathrm{~cm}$ ) at Site 541 and its probable corresponding level at Site 543 , which is simply a decrease in radiolarian abundance in Sample 543-19-4, 30-32 cm. On the other hand, if it is hypothesized that the Stichocorys wolffii Zone occurs in the void core Section 541-50-2, then that part of the section is thinner at Site 541 than at Site 543.

In general, the radiolarians occur in a more competent underlying section, which shows greater density and strength than the overlying hemipelagic deposits. The section resists off-scraping, maintaining its integrity, and appears to be subducted with the underlying oceanic crust.

As to the question raised by the absence of the middle Miocene radiolarians at Site 541 , the absence could be due to a hiatus or to tectonic thinning, but the evidence available is insufficient at this time to speculate further.

\section{SPECIES LIST}

This list provides bibliographic references to the species in this chapter. Only references to the original description and to the present concept of the species (indicated by-), if different from the original, are given.

Artophormis gracilis Riedel

Artophormis gracilis Riedel, 1959, p. 300, pl. 2, figs. 12, 13.

Buryella clinata Foreman

Buryella clinata Foreman, 1973, p. 433, pl. 8, figs. 1-3; pl. 9, fig. 19.

Calocyclas bandyca (Mato and Theyer)

Lychnocanoma bandyca Mato and Theyer, 1980, p. 225, pl. 1, figs. 1-6.

Calocyclas bandyca (Mato and Theyer)-Sanfilippo and Riedel, in Saunders et al., in press.

Calocyclas hispida (Ehrenberg)

Anthocyrtis hispida Ehrenberg, 1873, p. 216.

Calocyclas hispida (Ehrenberg)-Riedel and Sanfilippo, 1978, p. 65 , pl. 3 , fig. 6 .

Calocyclas turris Ehrenberg, 1873, p. 218; 1875, pl. 18, fig. 7; Riedel and Sanfilippo, 1978 , p. 65 , pl. 3 , figs. 7,8 .

Calocycletta costata (Riedel)

Calocyclas costata Riedel, 1959, p. 296, pl. 2, fig. 9.

Calocycletta costata (Riedel)-Riedel and Sanfilippo, 1978, p. 66, pl. 3, fig. 9 . 
G. W. RENZ

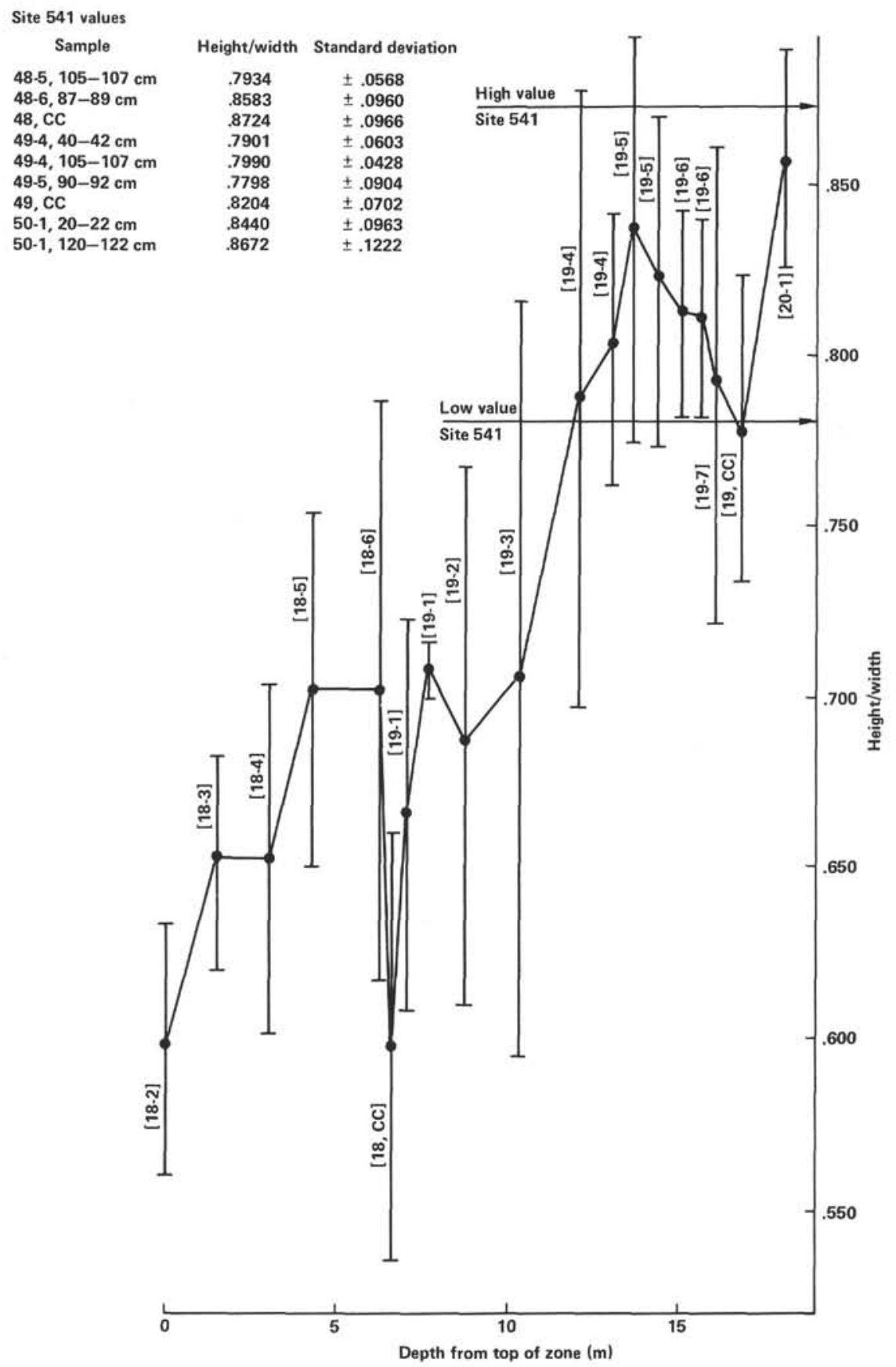

Figure 4. Thorax development of Cyclampterium leptetrum within the Calocycletta costata Zone at Site 543. (Depth in meters from top of $C$. costata Zone is indicated. Cores and sections are given in brackets.)

Calocycletta serrata Moore

Calocycletta serrata Moore, 1972, p. 148; pl. 2, figs. 1-3. Riedel and Sanfilippo, 1978, p. 66; pl. 3, fig. 12.

Calocycletta virginis Haeckel

Calocyclas (Calocycletta) virginis Haeckel, 1887, p. 1381, pl. 74, fig. 4.

Calocycletta virginis Haeckel-Riedel and Sanfilippo, 1978, p. 66, pl. 3, figs. 13, 14 .

Calocycloma ampulla (Ehrenberg)

Eucyrtidium ampulla Ehrenberg, 1854, pl. 36, fig. 15; 1873, p. 225.

Calocycloma ampulla (Ehrenberg)-Riedel and Sanfilippo, 1970, p. 524, pl. 6, fig. 1; Riedel and Sanfilippo, 1978, p. 66.
Calocycloma castum (Haeckel)

Calocyclas casta Haeckel, 1887 , p. 1384 , pl. 73, fig. 10.

Calocycloma castum (Haeckel)-Foreman, 1973, p. 434, pl. 1, figs. 7, 9, 10; Riedel and Sanfilippo, 1978, p. 66, pl. 1, fig. 9; pl. 3, fig. 15.

"Carpocanistrum" azyx Sanfilippo and Riedel

Carpocanistrum(?) azyx Sanfilippo and Riedel, 1973, p. 530, pl. 35 , fig. 9.

"Carpocanistrum" azyx Sanfilippo and Riedel, in Saunders et al., in press.

Carpocanopsis bramlettei Riedel and Sanfilippo

Carpocanopsis bramlettei Riedel and Sanfilippo, 1971, p. 1597, pl. 2G, figs. $8-14$; pl. 8, fig. $7 ; 1978$, p. 67 , pl. 4 , fig. 6 . 
Site 541 values

Sample

$48-5,105-107 \mathrm{~cm}$

48-6, 87-89 cm

48, CC

$49-4,40-42 \mathrm{~cm}$

$49-4,105-107 \mathrm{~cm}$

49-5, 90-92 cm

$49, \mathrm{CC}$

$50-1,20-22 \mathrm{~cm}$

$50.1,120-122 \mathrm{~cm}$

$\begin{array}{cc}H \times W\left(\mu^{2}\right) & \text { Standard deviation } \\ 3949 & \pm 530 \\ 4541 & \pm 121 \\ 4376 & \pm 240 \\ 3879 & \pm 265 \\ 3857 & \pm 133 \\ 4264 & \pm 268 \\ 4186 & \pm 332 \\ 4164 & \pm 364 \\ 3880 & \pm 497\end{array}$
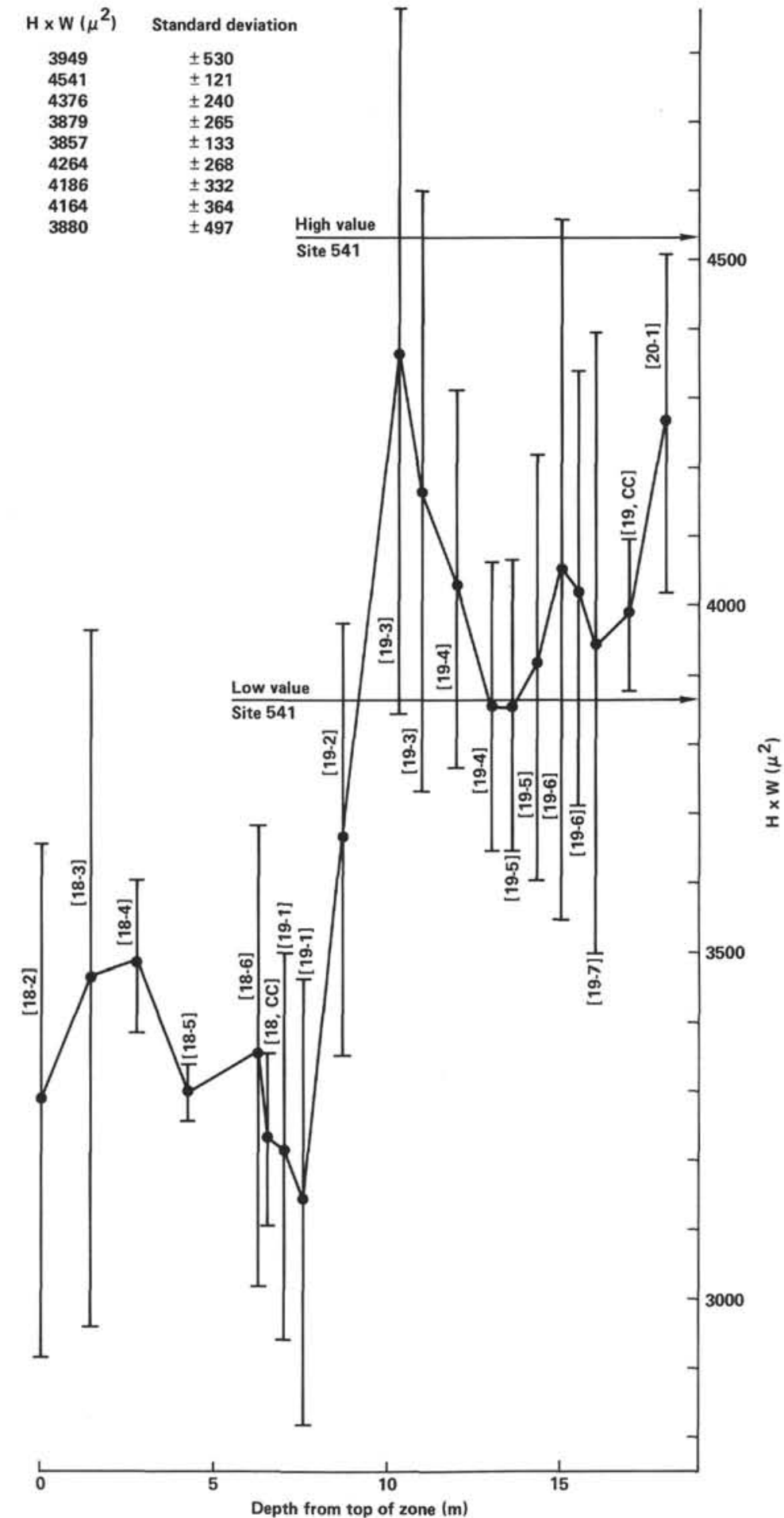

Figure 5. Cephalis development of Dorcadospyris dentata within the Calocycletta costata Zone at Site 543. (Depth in meters from top of $C$. costata Zone is indicated. Cores and sections are given in brackets.)

Carpocanopsis cingulata Riedel and Sanfilippo.

Carpocanopsis cingulata Riedel and Sanfilippo, 1971, p. 1597, pl. 2G, figs. 17-21; pl. 8, Fig. 8; 1978, p. 67, pl. 4, fig. 4.

\section{Cryptoprora ornata Ehrenberg}

Cryptoprora ornata Ehrenberg, 1873, p. 222; 1875, pl. 5, fig. 8; Sanfilippo and Riedel, in Saunders et al., in press.
Cyclampterium leptetrum Sanfilippo and Riedel

Cyclampterium leptetrum Sanfilippo and Riedel, 1970, p. 456, pl. 2 , figs. 11,12 .

Cyclampterium milowi Riedel and Sanfilippo

Cyclampterium milowi Riedel and Sanfilippo, 1971, p. 1593, pl. 3B, fig. 3; pl. 7, figs. 8-9; Riedel and Sanfilippo, 1978, p. 67, pl. 4 , fig. 14 . 


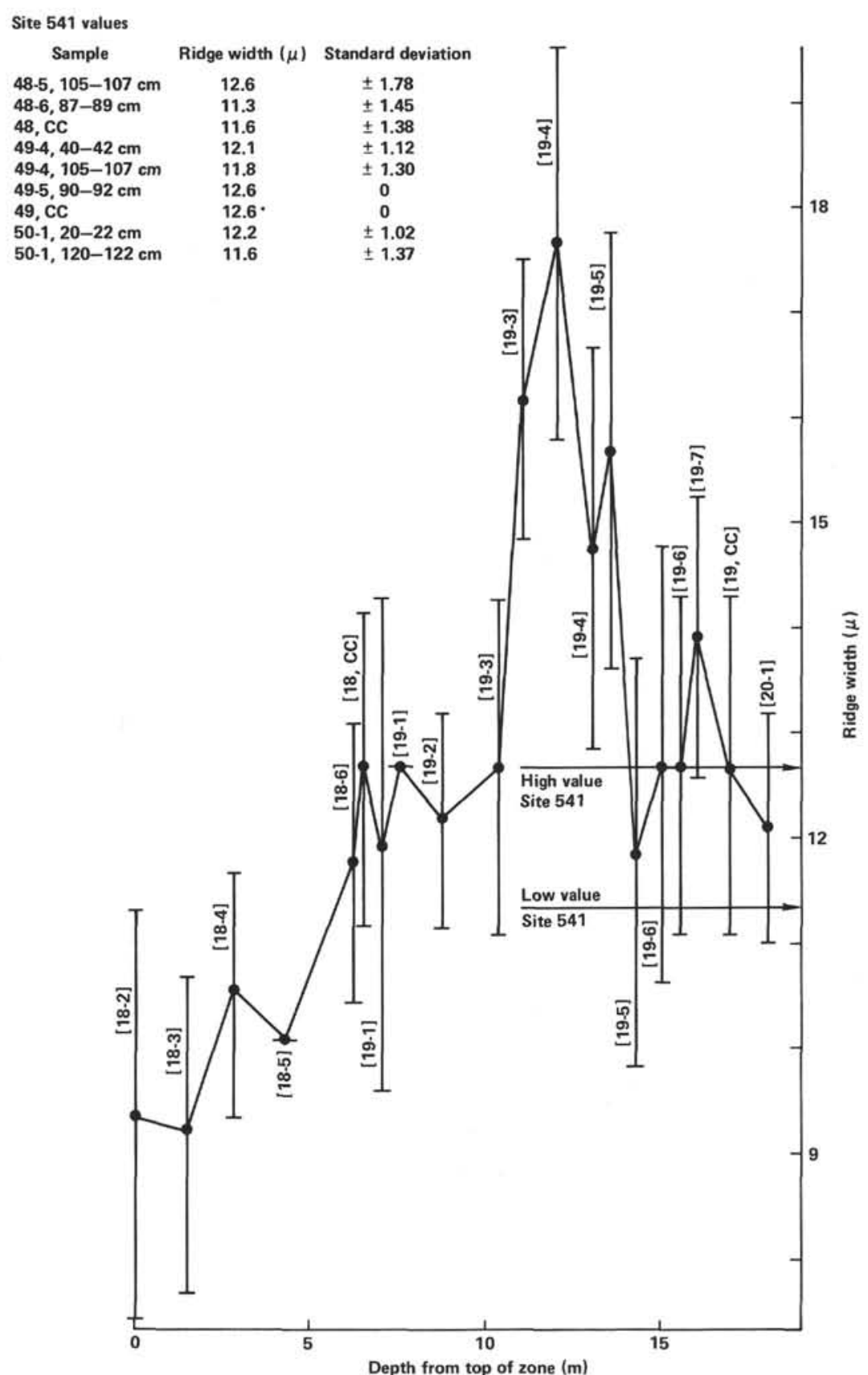

Figure 6. Thoracic ridge development of Calocycletta costata within the Calocycletta costata Zone at Site 543. (Depth in meters from top of $C$. costata Zone is indicated. Cores and sections are given in brackets.)

Cyclampterium pegetrum Sanfilippo and Riedel

Cyclampterium pegetrum Sanfilippo and Riedel, 1970, p. 456, pl. 2, figs. 8-10; Riedel and Sanfilippo, 1978, p. 68, pl. 4, fig. 16. Cyrtocapsella cornuta Haeckel

Cyrtocapsa (Cyrtocapsella) cornuta Haeckel, 1887, p. 1513, pl. 78, fig. 9.

Cyrtocapsella cornuta Haeckel-Riedel and Sanfilippo, 1978, p. 68 , pl. 4, fig. 17.

Cyrtocapsella tetrapera Haeckel

Cyrtocapsa (Cyrtocapsella) tetrapera Heackel, 1887, p. 1512, pl. 78 , fig. 5.

Cyrtocapsella tetrapera Haeckel-Riedel and Sanfilippo, 1978, p. 68 , pl. 4 , fig. 18 .
Dictyophimus craticula Ehrenberg

Dictyophimus craticula Ehrenberg, 1873, p. 223; Riedel and Sanfilippo, 1978, p. 68, pl. 4, fig. 19.

Dictyoprora armadillo (Ehrenberg) group

Eucyrtidium armadillo Ehrenberg, 1873, p. 225; 1875, pl. 9, fig. 10.

Dictyoprora armadillo (Ehrenberg) group-Nigrini, 1977, p. 250, pl. 4 , fig. 4 .

Dictyoprora mongolfieri (Ehrenberg)

Eucyrtidium mongolfieri Ehrenberg, 1854, pl. 36, fig. 18B, lower. Dictyoprora mongolfieri (Ehrenberg)-Nigrini, 1977, p. 250, pl. 4, fig. 7. 
Didymocyrtis prismatica (Haeckel)

Pipettella prismatica Haeckel, 1887, p. 305, pl. 39, fig. 6.

Didymocyrtis prismatica (Haeckel)-Sanfilippo and Riedel, 1980, p. 1010, text fig. 1c.

Didymocyrtis tubaria (Haeckel)

Pipettella tubaria Haeckel, 1887, p. 339, pl. 39, fig. 15.

Didymocyrtis tubaria (Haeckel)-Sanfilippo and Riedel, 1980, p. 1010.

Didymocyrtis violina (Haeckel)

Cannartus violina Haeckel, 1887, p. 358, pl. 39, fig. 10; Riedel, 1959 , p. 290 , pl. 1 , fig. 3.

Didymocyrtis violina (Haeckel)-Sanfilippo and Riedel, 1980, p. 1010 , text fig. 1d.

Dorcadospyris alata (Riedel)

Brachiospyris alata Riedel, 1959, p. 293, pl. 1, figs. 11, 12.

Dorcadospyris alata (Riedel)-Riedel and Sanfilippo, 1978, p. 68, pl. 5, fig. 2.

Dorcadospyris ateuchus (Ehrenberg)

Ceratospyris ateuchus Ehrenberg, 1873, p. 218.

Dorcadospyris ateuchus (Ehrenberg)-Riedel and Sanfilippo, 1978 , p. 68 , pl. 5 , fig. 3 .

Dorcadospyris dentata Haeckel

Dorcadospyris dentata Haeckel, 1887, p. 1040, pl. 85, fig. 6; Riedel and Sanfilippo, 1978, p. 68, pl. 5, fig. 4.

Eucyrtidium diaphanes Sanfilippo and Riedel

Eucyrtidium diaphanes Sanfilippo and Riedel, in Sanfilippo et al., 1973 , p. 221 , pl. 5, figs. $12-14$.

Eusyringium fistuligerum (Ehrenberg)

Eucyrtidium fistuligerum Ehrenberg, 1873, p. 229; 1875, pl. 9, fig. 3.

Eusyringium fistuligerum (Ehrenberg)-Saunders et al., in press.

Eusyringium lagena (Ehrenberg)

Lithopera lagena Ehrenberg, 1873, p. 241; 1875, pl. 3, fig. 4.

Eusyringium lagena (Ehrenberg)-Riedel and Sanfilippo, 1970, p. 527, pl. 8, figs. 5-7.

Lamptonium fabaeforme chaunothorax Riedel and Sanfilippo

Lamptonium(?) fabaeforme(?) chaunothorax Riedel and Sanfilippo, 1970 , p. 524 , pl. 5, figs. 8 , 9-Riedel, Sanfilippo, and Westberg, in Bolli et al., in press.

Lamptonium fabaeforme constrictum Riedel and Sanfilippo

Lamptonium(?) fabaeforme(?) constrictum Riedel and Sanfilippo, 1970 , p. 523, pl. 5, fig. 7-Riedel, Sanfilippo, and Westberg, in Bolli et al., in press.

Lamptonium fabaeforme fabaeforme (Krasheninnikov)

(?)Cyrtocalpis fabaeformis Krasheninnikov, 1960, p. 296, pl. 3, fig. 11.

Lamptonium fabaeforme fabaeforme (Krasheninnikov), Riedel and Sanfilippo, 1970, p. 523-Riedel, Sanfilippo, and Westberg, in Bolli et al., in press.

Liriospyris parkerae Riedel and Sanfilippo

Liriospyris parkerae Riedel and Sanfilippo, 1971, p. 1590, pl. 2C, fig. $15 ;$ pl. 5 , fig. 4.

Liriospyris stauropora (Haeckel)

Trissocyclus stauroporus Haeckel, 1887, p. 987, pl. 83, fig. 5.

Liriospyris stauropora (Haeckel)-Riedel and Sanfilippo, 1971, p. 1590 , pl. 2C, figs. 16-19.

Lithochytris vespertilio Ehrenberg

Lithochytris vespertilio Ehrenberg, 1873, p. 239; Riedel and Sanfilippo, 1978, p. 69, pl. 6, fig. 4.

Lithocyclia angusta (Riedel)

Trigonactura angusta Riedel, 1959, p. 292, pl. 1, fig. 6.

Lithocyclia angusta (Riedel), Riedel and Sanfilippo, 1970, p. 522, pl. 13, figs. 1,2 .

Lithocyclia aristotelis (Ehrenberg) group

Astromma aristolelis Ehrenberg, 1847, p. 55, fig. 10.

Lithocyclia aristotelis (Ehrenberg) group, Riedel and Sanfilippo, 1970 , p. 522.

Lithocyclia crux Moore

Lithocyclia crux Moore, 1971, p. 737, pl. 6, fig. 4.

Lophocyrtis jacchia (Ehrenberg)

Thyrsocyrtis jacchia Ehrenberg, 1873, p. 261; 1875, pl. 12, fig. 7.

Lophocyrtis jacchia (Ehrenberg), Riedel and Sanfilippo, 1971, p. 1594, pl. 3C, figs. 4, 5; pl. 7, fig. 16.
Lychnocanoma amphitrite Foreman

Lychnocanoma amphitrite Foreman, 1973, p. 437, pl. 11, fig. 10; Riedel, Sanfilippo, and Westberg, in Bolli et al., in press.

\section{Lychnocanoma bajunensis n. sp.}

(Plate 1, Figs. 4-6)

Description. Spherical cephalis has a few very small pores and a slight apical spine or thorn. The thorax is rounded-conical with small, round, wide-set pores quincuncially arranged in vertical rows. Three thin to moderately robust, bladed, solid legs arise from the lower thorax above a short, smooth peristome. Legs are quite long, flared, slightly curved to angular proximally, with convexity outward.

Measurements. Based on 20 specimens from Samples 543-27-3, 53-55 cm; 543-29-4, 73-75 cm; 543-29-5, 14-16 cm; and 543-30-4, 60$62 \mathrm{~cm}$. Length of cephalis plus thorax: mean $(\bar{x})=84.8 \mu \mathrm{m}$, range: 74.8-99.8 $\mu \mathrm{m}$. Maximum breadth of thorax: $\overline{\mathrm{x}}=85.0 \mu \mathrm{m}$, range: $79.0-99.8 \mu \mathrm{m}$. Length of legs (on a straight measure from lower thorax to toe): $\overline{\mathrm{x}}=289.4 \mu \mathrm{m}$, range: $208.0-403.5 \mu \mathrm{m}$. Maximum distance between legs: $\overline{\mathrm{x}}=284.5 \mu \mathrm{m}$, range: 199.7-328.6 $\mu \mathrm{m}$. Diameter of peristome: $\bar{x}=43.7 \mu \mathrm{m}$, range: $33.3-58.2 \mu \mathrm{m}$.

Distinctions from other species. This species differs from a number of Lychnocanoma species (including Ehrenberg's 1875 Lychnocanoma tripodium, $L$. trichopus, and $L$. carinatum, and others not yet described) in having the following combination of characters: longer, less robust legs, a regular pore arrangement over the entire thorax (not poreless proximally), and a more rounded-conical thorax without ribs.

Remarks. This species ranges from the bottom of the Dictyoprora mongolfieri Zone of the middle Eocene to the top of the Cryptoprora ornata Zone near the Eocene/Oligocene boundary. At the end of its range, specimens have a larger thorax, wider mouth, and more prominent apical horn. The legs appear to arise lower on the thorax and tend to be shorter and more robust.

The specific name bajunensis is derived from the colloquial adjective "bajun" meaning "of Barbados",

Lychnocanoma elongata (Vinassa)

Tetrahedrina elongata Vinassa, 1900, p. 243, pl. 2, fig. 31.

Lychnocanoma elongata (Vinassa)-Riedel and Sanfilippo, 1978, p. 70 , pl. 7, fig. 4 .

Periphaena delta Sanfilippo and Riedel

Periphaena delta Sanfilippo and Riedel, 1973, p. 523, pl. 8, figs. 11-12; pl. 27, figs. 6, 7 .

Podocyrtis ampla Ehrenberg

Podocyrtis(?) ampla Ehrenberg, 1873, p. 248; 1875, pl. 16, fig. 7.

Podocyrtis (Podocyrtis) ampla Ehrenberg, Riedel and Sanfilippo, 1970, p. 533; Riedel, Sanfilippo, and Westberg, in Bolli et al., in press.

Podocyrtis aphorma Riedel and Sanfilippo

Podocyrtis (Lampterium) aphorma Riedel and Sanfilippo, 1970, p. 534.

Podocyrtis chalara Riedel and Sanfilippo

Podocyrtis (Lampterium) chalara Riedel and Sanfilippo, 1970, p. 535, pl. 12, figs. 2, 3; 1978, text fig. 3; Riedel, Sanfilippo, and Westberg, in Bolli et al., in press.

Podocyrtis diamesa Riedel and Sanfilippo

Podocyrtis (Podocyrtis) diamesa Riedel and Sanfilippo, 1970, p. 533 (pars), pl. 12, fig. 4, non figs. 5 and 6; Riedel, Sanfilippo, and Westberg, in Bolli et al., in press.

Podocyrtis dorus Sanfilippo and Riedel

Podocyrtis (Podocyrtis) dorus Sanfilippo and Riedel, 1973, p. 531. Podocyrtis fasciolata Nigrini

Podocyrtis (Podocyrtis) ampla fasciolata Nigrini, 1974, p. 1069, pl. $1 \mathrm{~K}$, figs. 1, 2; pl. 4, figs. 2, 3.

Podocyrtis (Lampterium) fasciolata Nigrini; Riedel, Sanfilippo, and Westberg, in Bolli et al., in press.

Podocyrtis goetheana (Haeckel)

Cycladophora goetheana Haeckel, 1887, p. 1376, pl. 65, fig. 5 .

Podocyrtis (Lampterium) goetheana (Haeckel), Riedel and Sanfilippo, 1970, p. 534; Riedel, Sanfilippo, and Westberg, in Bolli et al., in press.

Podocyrtis mitra Ehrenberg

Podocyrtis mitra Ehrenberg, 1854, pl. 36, fig. B20.

Podocyrtis (Lampterium) mitra Ehrenberg-Riedel, Sanfilippo, and Westberg, in Bolli et al., in press. 
Podocyrtis papalis Ehrenberg

Podocyrtis papalis Ehrenberg, 1847, fig. 2; Riedel and Sanfilippo, 1970 , p. 532, pl. 11, fig. 1.

Podocyrtis phyxis Sanfilippo and Riedel

Podocyrtis phyxis Sanfilippo and Riedel, 1973, p. 531.

Podocyrtis (Podocyrtis) phyxis Sanfilippo and Riedel in Riedel, Sanfilippo, and Westberg, in Bolli et al., in press.

Podocyrtis sinuosa Ehrenberg

Podocyrtis sinuosa Ehrenberg, 1873, p. 253; 1875, pl. 15, fig. 5 .

Podocyrtis (Lampterium) sinuosa Ehrenberg, Riedel, Sanfilippo, and Westberg, in Bolli et al., in press.

Podocyrtis trachodes Riedel and Sanfilippo

Podocyrtis (Lampterium) trachodes Riedel and Sanfilippo, 1970, p. 535 , pl. 11, fig. 7 ; pl. 12, fig. 1; Riedel, Sanfilippo, and Westberg, in Bolli et al., in press.

Rhabdolithis pipa Ehrenberg

Rhabdolithis pipa Ehrenberg, 1854, pl. 36, fig. 59; Riedel and Sanfilippo, 1978, p. 72, pl. 9, figs. 3, 4 .

Sethochytris babylonis (Clark and Campbell) group

Dictyophimus babylonis Clark and Campbell, 1942, p. 67, pl. 9, figs. 32,36 .

Sethochytris babylonis (Clark and Campbell) group, Riedel and Sanfilippo, 1970, p. 528, pl. 9, figs. 1-3.

Sethochytris triconiscus Haeckel

Sethochytris triconiscus Haeckel, 1887, p. 1239, pl. 57, fig. 13; Riedel, Sanfilippo, and Westberg, in Bolli et al., in press.

Siphostichoartus corona (Haeckel)

Crytophormis (Acanthocyrtis) corona Haeckel, 1887, p. 1462, pl. 77, fig. 15.

Phormostichoartus corona (Haeckel)-Riedel and Sanfilippo, 1978, p. 71, pl. 7, fig. 12 .

Siphostichoartus corona (Haeckel)-Nigrini, 1977, p. 257, pl. 2, figs. 5-7.

Stichocorys delmontensis (Campbell and Clark)

Eucyrtidium delmontense Campbell and Clark, 1944, p. 56, pl. 7, figs. 19,20

Stichocorys delmontensis (Campbell and Clark)-Riedel and Sanfilippo, 1978, p. 74, pl. 9, fig. 10.

Stichocorys wolffii Haeckel

Stichocorys wolffii Haeckel, 1887, p. 1479, pl. 80, fig. 10; Riedel, Sanfilippo, and Westberg, in Bolli et al., in press.

Theocorys anaclasta Riedel and Sanfilippo, 1970, p. 530, pl. 10, figs.

2, 3; Riedel, Sanfilippo, and Westberg, in Bolli et al., in press.

Theocorys spongoconum Kling

Theocorys spongoconum Kling, 1971, p. 1087, pl. 5, fig. 6; Riedel and Sanfilippo, 1978, p. 76, pl. 9, fig. 16.

Theocotyle cryptocephala (Ehrenberg)

Eucyrtidium cryptocephalum Ehrenberg, 1873, p. 227.

Theocotyle cryptocephala (Ehrenberg)-Sanfilippo and Riedel, 1982 , p. 178 , pl. 2, figs. 4-7.

Theocotyle nigriniae Riedel and Sanfilippo

Theocorys sp. Nigrini, in Cita et al., 1970, pl. 2, fig. L.

Theocotyle nigriniae Riedel and Sanfilippo-Sanfilippo and Riedel, 1982, p. 178, pl. 2, figs. 1-3.

Theocotyle venezuelensis Riedel and Sanfilippo

Theocotyle venezuelensis Riedel and Sanfilippo, 1970, p. 525, pl. 6, figs. 9, 10; pl. 7, figs. 1, 2; Sanfilippo and Riedel, 1982, p. 179 , pl. 2, figs. 8-12.

Theocotylissa ficus (Ehrenberg)

Eucyrtidium ficus Ehrenberg, 1873, p. 228; 1875, pl. 11, fig. 19.

Theocotylissa ficus (Ehrenberg)-Sanfilippo and Riedel, 1982, p. 180 , pl. 2 , figs. $19-20$.

Theocyrtis annosa (Riedel)

Phormocyrtis annosa Riedel, 1959, p. 295, pl. 2, fig. 7.

Theocyrtis annosa (Riedel)-Riedel and Sanfilippo, 1978, p. 78, pl. 10, fig. 3.

Theocyrtis tuberosa Riedel

Theocyrtis turberosa Riedel, 1959, p. 298, pl. 2, figs. 10, 11; Riedel, Sanfilippo, and Westberg, in Bolli et al., in press.

Thyrsocyrtis bromia Ehrenberg

Thyrsocyrtis bromia Ehrenberg, 1873, p. 260; 1875, pl. 12, fig. 2; Sanfilippo and Riedel, 1982, p. 172, pl. 1, figs. 17-20.
Thyrsocyrtis hirsuta (Krasheninnikov)

Podocyrtis hirsutus Krasheninnikov, 1960, p. 300, pl. 3, fig. 16.

Thyrsocyrtis (Thyrsocyrtis) hirsuta (Krasheninnikov), Sanfilippo and Riedel, 1982, p. 173, pl. 1, figs. 3, 4.

Thyrsocyrtis rhizodon Ehrenberg

Thyrosocyrtis rhizodon Ehrenberg, 1873, p. 262; 1875, pl. 12, fig.

Thyroscyrtis (Thyrsocyrtis) rhizodon Ehrenberg-Sanfilippo and Riedel, 1982, p. 173, pl. 1, figs. 14-16, pl. 3, figs. 12-17.

Thyrsocyrtis robusta Riedel and Sanfilippo

Thyrsocyrtis hirsuta robusta Riedel and Sanfilippo, 1970, p. 526, pl. 8 , fig. 1 .

Thyrsocyrtis (Thyrsocyrtis) robusta Riedel and Sanfilippo-Sanfilippo and Riedel, 1982, p. 174, pl. 1, fig. 5.

Thyrsocyrtis tensa Foreman

Thyrsocyrtis(?) sp. Foreman, 1973, pl. 3, figs. 18-19; pl. 12, figs. $7,12$.

Thyrsocyrtis (Pentalacorys) tensa Foreman-Sanfilippo and Riedel, 1982, p. 176, pl. 1, figs. 6, 7; pl. 3, figs. 1, 2.

Thyrsocyrtis tetracantha (Ehrenberg)

Podocyrtis tetracantha Ehrenberg, 1873, p. 253; 1875, pl. 13, fig. 2.

Thyrsocyrtis (Pentalacorys) tetracantha (Ehrenberg)-Sanfilippo and Riedel, 1982, p. 176, pl. 1, figs. 11-12; pl. 3, fig. 10.

Thyrsocyrtis triacantha (Ehrenberg)

Podocyrtis triacantha Ehrenberg, 1873, p. 254, 1875, pl. 13, fig. 4.

Thyrsocyrtis (Pentalacorys) triacantha (Ehrenberg) Sanfilippo and Riedel, 1982, p. 176, pl. 1, figs. 8-10; pl. 3, figs. 3, 4.

Tristylospyris triceros (Ehrenberg)

Ceratospyris triceros Ehrenberg, 1873, p. 220.

Tristylospyris triceros (Ehrenberg)-Haeckel, 1887, p. 1033; Riedel and Sanfilippo, 1978, p. 82, pl. 10, fig. 12.

\section{ACKNOWLEDGMENTS}

I would like to thank sincerely W. R. Riedel and Annika Sanfilippo for their initiation and unending support of this research.

\section{REFERENCES}

Campbell, A. S., and Clark, B. L., 1944. Miocene radiolarian faunas from Southern California. Geol. Soc. Am., Spec. Paper 51:1-76.

Cita, M. B., Nigrini, C., and Gartner, S., 1970. Biostratigraphy. In Peterson, M. N. A., Edgar, N. T., et al., Init. Repts. DSDP, 2: Washington (U.S. Govt. Printing Office), 391-411.

Clark, B. L., and Campbell, A. S., 1942. Eocene radiolarian faunas from the Mt. Diablo area, California. Geol. Soc. Am., Spec. Paper 39.

Ehrenberg, C. G., 1847. Über die mikroskopischen kieselschaligen Polycystinen als mächtige Gebirgsmasse von Barbados und über das Verhältniss der aus mehr als 300 neuen Arten bestehenden ganz eigenthümlichen Formengruppe jener Felsmasse zu den jetzt lebenden Thieren und zur Kreidegebildung. Eine neue Anregung zur Erforschung des Erdlebens. Königlichen Preussischen Akademie der Wissenschaften: Berlin (Bericht), pp. 40-60. 1854. Mikrogeologie: Leipzig (Leopold Voss).

1873. Grössere Felsproben des Polycystinen-Mergels von Barbados mit weiteren Erläuterungen. Königlichen Preussischen Akademie der Wissenschaften, Berlin (Monatsberichte), pp. 213263.

1875. Fortsetzung der mikrogeologischen Studien als Gesammt-Uebersicht der mikroskopischen Paläontologie gleichartig analysirter Gebirgsarten der Erde, mit specieller Rücksicht auf den Polycystinen-Mergel von Barbados. K. Akad. Wiss. Berlin, Abh. Jahre, 1875:1-225.

Foreman, H. P., 1973. Radiolaria of Leg 10 with systematics and ranges for the families Amphipyndacidae, Artostrobiidae, and Theoperidae. In Worzel, J. L., Bryant, W., et al., Init. Repts. DSDP, 10: Washington (U.S. Govt. Printing Office), 407-474.

Haeckel, E., 1887, Report on the Radiolaria collected by H.M.S. Challenger during the years 1873-76. Report on the Scientific Results of the Voyage of the H.M.S. Challenger. Zoology, 18: 1-1303. 
Kling, S. A., 1971. Radiolaria: Leg 6 of the Deep Sea Drilling Project. In Fischer, A. G., Heezen, B. C., et al., Init. Repts. DSDP, 6: Washington (U.S. Govt. Printing Office), 1069-1117.

Krasheninnikov, V. A., 1960. Nekotorye radiolyarii nizhnego i srednego eotsena Zapadnogo Predkavkazya. Vses. Nauchno-Issled, Geol.Razved. Neft. Inst. (VNIGNI), Trudy, 16, pp. 271-301.

Mato, C. Y., and Theyer, F., 1980. Lychnocanoma bandyca n. sp., a new stratigraphically important late Eocene radiolarian. In Sliter, W. V. (Ed.), Studies in Marine Micropaleontology and Paleoecology; a Memorial Volume to Orville L. Bandy, Cushman Foundation for Foraminiferal Research, Spec. Publ. 19(1 pl.):225-229.

Maurrasse, F., and Glass, B., 1976. Radiolarian stratigraphy and North American microtektites in Caribbean RC9-58; implications concerning late Eocene radiolarian chronology and the age of the Eocene/Oligocene boundary. In Publication de la VII Conférence Géologique des Caraỉbes du 30 Juin au 12 Juillet 1974, Cayenne, Départment Français de la Guyane, pp. 205-212.

Moore, T. C., Jr., 1971. Radiolaria. In Tracey, J. L., Jr., Sutton, G. H., et al., Init. Repts. DSDP, 8: Washington (U.S. Govt. Printing Office), 727-775.

1972. Mid-Tertiary evolution of the radiolarian genus Calocycletta. Micropaleontology, 18:144-152.

Nigrini, C., 1974. Cenozoic Radiolaria from the Arabian Sea, DSDP Leg 23. In Davies, T. A., Luyendyk, B. P., et al., Init. Repts. DSDP, 26: Washington (U.S. Govt. Printing Office), 1051-1121. , 1977. Tropical Cenozoic Artostrobiidae (Radiolaria). Micropaleontology, 23(No. 3):241-269.

Riedel, W. R., 1959. Oligocene and lower Miocene Radiolaria in tropical Pacific sediments. Micropaleontology, 5:285-302.

Riedel, W. R., and Sanfilippo, A., 1970. Radiolaria, Leg 4, Deep Sea Drilling Project. In Bader, R. G., Gerard, R. D., et al. Init. Repts. DSDP, 4: Washington (U.S. Govt. Printing Office), 503-575. 1971. Cenozoic Radiolaria from the western tropical Pacific, Leg 7. In Winterer, E. L., Riedel, W. R., et al., Init. Repts. DSDP, 7, Pt. 1: Washington (U.S. Govt. Printing Office), 15291672.

1973. Cenozoic Radiolaria from the Caribbean, Deep Sea Drilling Project, Leg 15. In Edgar, N. T., Saunders, J. B., et al.,
Init. Repts. DSDP, 15: Washington (U.S. Govt. Printing Office), 705-751.

1978. Stratigraphy and evolution of tropical Cenozoic radiolarians. Micropaleontology, 24(1):61-96.

Riedel, W. R., Sanfilippo, A., and Westberg, J., in press. Cenozoic Radiolaria. In Bolli, H. M., Perch-Nielsen, K., and Saunders, J. B. (Eds.), Biostratigraphy by Marine Plankton: Cambridge (Cambridge University Press).

Riedel, W. R., and Westberg, M. J., 1982. Neogene Radiolarians from the eastern tropical Pacific and Caribbean. In Prell, W. L., Gardner, J. V., et al., Init. Repts. DSDP, 68: Washington (U.S. Govt. Printing Office), 289-300.

Sanfilippo, A., Burckle, L. H., Martini, E., and Riedel, W. R., 1973. Radiolarians, diatoms, silicoflagellates and calcareous nannofossils in the Mediterranean Neogene. Micropaleontology, 19(2):209234.

Sanfilippo, A., and Riedel, W. R., 1970. Post-Eocene "closed" theoperid radiolarians. Micropaleontology, 16(4):446-462.

1973. Cenozoic Radiolaria (exclusive of theoperids, artostrobiids, and amphipyndacids) from the Gulf of Mexico, DSDP Leg 10. In Worzel, J. L., Bryant, W., et al., Init. Repts. DSDP, 10: Washington (U.S. Govt. Printing Office), 475-611.

1976. Radiolarian occurrences in the Caribbean region. In Publication de la VII Conférence géologique des Caraỉbes du 30 Juin au 12 Juillet 1974, Cayenne, Départment Français de la Guyane, pp. 145-168.

1980. A revised generic and suprageneric classifiation of the Artiscins (Radiolaria). J. Paleontol., 54(5):1008-1012. 1982. Revision of the radiolarian genera Theocotyle, Theocotyliss $a$ and Thyrsocyrtis. Micropaleontology, 28(2):170-188.

Saunders, J. B., Bernoulli, D., Müller-Merz, E., Oberhänsli, H., Perch-Nielsen, K., Riedel, W. R., Sanfilippo, A. B., and Torrini, $\mathrm{R}$., Jr., in press. Stratigraphy of the late-middle Eocene to early Oligocene in the Bath Cliff section, Barbados, West Indies. Micropaleontology.

Vinassa de Regny, P., 1900. Radiolari miocenici italiani. Mem. R. Accad. Sci. Ist. Bologna, Ser. 5, 8:227-257. 

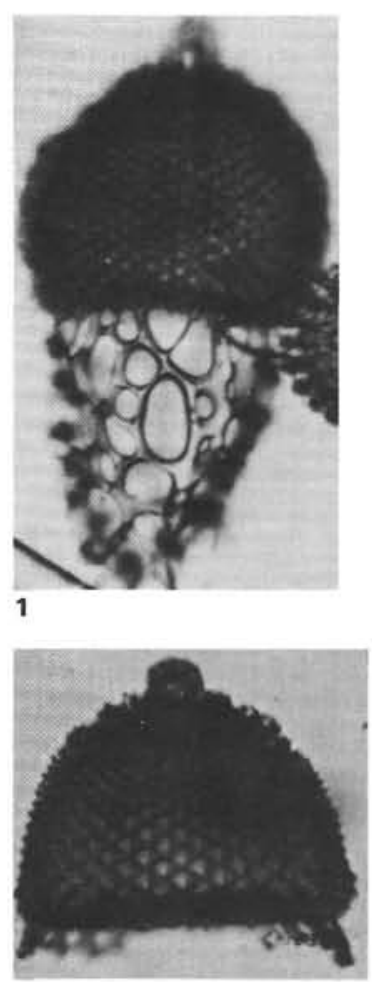

3

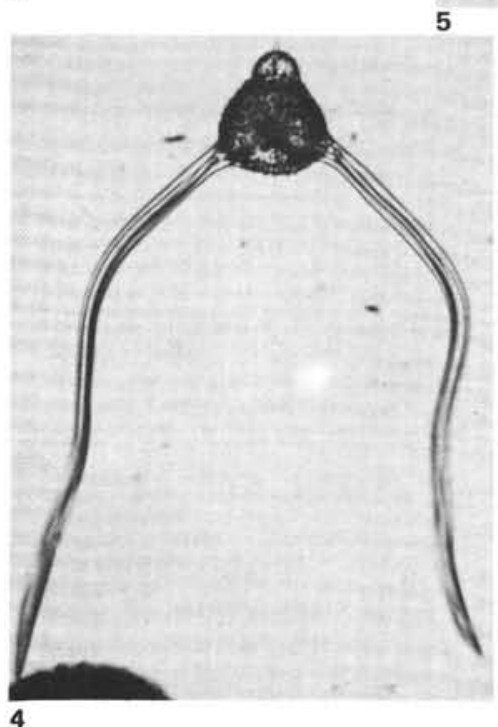

2
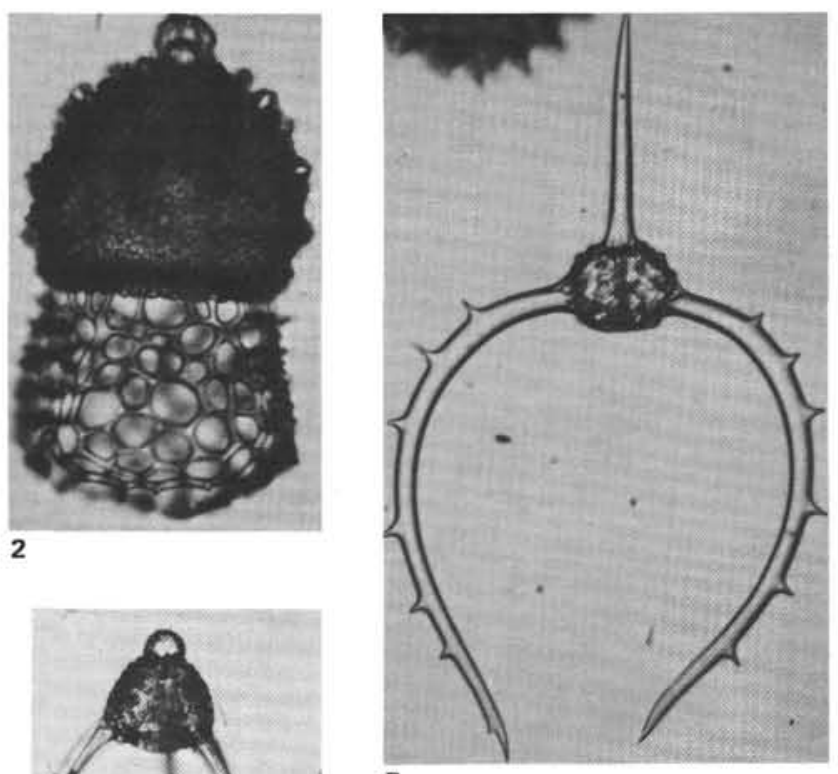

7
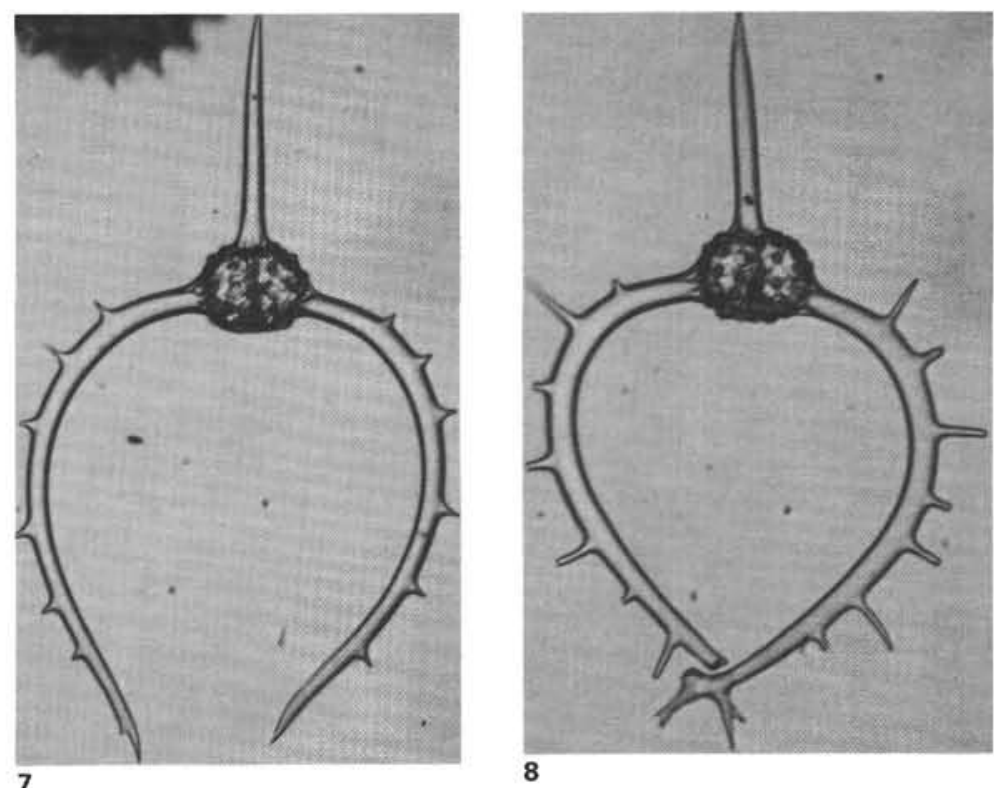

8

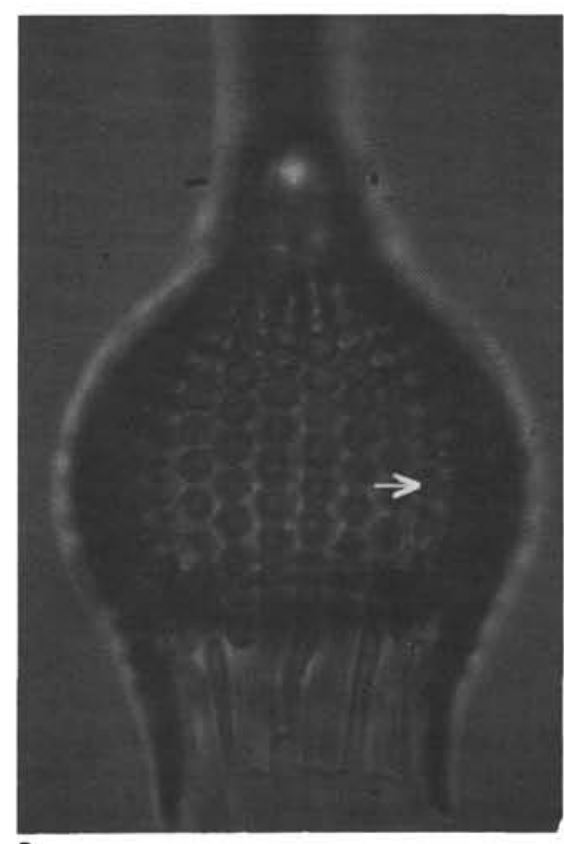

9

Plate 1. 1-3. Cyclampterium leptetrum Sanfilippo and Riedel, (1) Sample 541-49-4, 105-107 cm, C2; $\times 135$, (2) Sample 543-19-6, 113-115 cm, C2; $\times 135$, (3) Sample 543-18-3, 31-33 cm, C1; $\times 135$. 4-6. Lychnocanoma bajunensis $\mathrm{n}$. sp. (4) holotype; Sample 543-29-5, 14-16 cm, C1, J/42-1; $\times 135$, (5) specimen showing 3 legs; Sample $543-29-5,125-127 \mathrm{~cm}, \mathrm{C} 2, \mathrm{~K} / 15-0 ; \times 135$, (6) close-up of leg structure; arrows indicate 3 silica arches making up a bladed leg and surrounding a pore; Sample 543-29-5, 14-16 cm, C1, $\phi / 27-4 ; \times 860$. 7,8. Dorcadospyris dentata Haeckel, (7) Sample 543-18-2, 31-33 cm, C1, × 135, (8) Section 543-19,CC, C1, ×135. 9. Calocycletta costata (Riedel); Section 543-19, CC, C1, V/39-0; $\times 550$, arrow indicates width of ridge. 